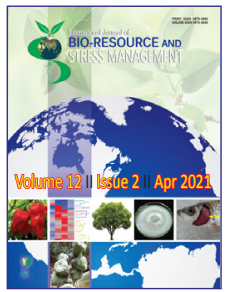

Article AR2150a

DOI: HTTPS://DOI.ORG/10.23910/1.2021.2150a

International Journal of Bio-resource and Stress Management

April 2021

Print ISSN 0976-3988

Online ISSN 0976-4038

IJBSM 2021, 12(2):095-107

Research Article

Natural Resource Management

\title{
Agronomic Biofortification of Zinc in Lentil
}

\author{
Mrinmoy Karmakar ${ }^{1}$, Narayan Chandra Sarkar ${ }^{1 *}$ and Yashbir Singh Shivay ${ }^{2}$
}

${ }^{1}$ Dept. of Agronomy, Institute of Agriculture (Palli Siksha Bhavana), Visva-Bharati, Sriniketan, Birbhum, W.B. (731 236), India

${ }^{2}$ Division of Agronomy, Indian Agricultural Research Institute, New Delhi (110 012), India

\begin{abstract}
Open Access
Corresponding Author

Narayan Chandra Sarkar

e-mail: narayanchandra.sarkar@visva-bharati.ac.in

Citation: Karmakar et al., 2021. Agronomic Biofortification of Zincin Lentil. International Journal of Bio-resource and Stress Management 2021, 12(2), 095107. HTTPS://DOI.ORG/10.23910/1.2021.2150a.

Copyright: (c) 2021 Karmakar et al. This is an open access article that permits unrestricted use, distribution and reproduction in any medium after the author(s) and source are credited.

Data Availability Statement: Legal restrictions are imposed on the public sharing of raw data. However, authors have full right to transfer or share the data in raw form upon request subject to either meeting the conditions of the original consents and the original research study. Further, access of data needs to meet whether the user complies with the ethical and legal obligations as data controllers to allow for secondary use of the data outside of the original study.
\end{abstract}

Conflict of interests: The authors have declared that no conflict of interest exists.

\begin{abstract}
The field experiments were conducted to study effect of zinc $(\mathrm{Zn})$ application on growth, yield, $\mathrm{Zn}$ uptake and $\mathrm{Zn}$ use indices of lentil (Lens culinaris or Lens esculanta) during rabi (October to March) seasons 2016 and 2017 in red and lateritic soil of West Bengal, India. There were two main plot treatments i.e., crop establishment methods (zero tillage and conventional tillage) and seven sub-plot treatments i.e. levels of $\mathrm{Zn}$ and methods of application (seed coating @ $0.6 \% \mathrm{ZnSO}_{4} .7 \mathrm{H}_{2} \mathrm{O}, 1.2 \% \mathrm{ZnSO}_{4} .7 \mathrm{H}_{2} \mathrm{O}$ and $1.8 \% \mathrm{ZnSO}_{4} .7 \mathrm{H}_{2} \mathrm{O}$, two foliar sprays @ $0.5 \% \mathrm{ZnSO}_{4} .7 \mathrm{H}_{2} \mathrm{O}$, three foliar sprays @ $0.5 \% \mathrm{ZnSO}_{4} .7 \mathrm{H}_{2} \mathrm{O}$, seed coating @ $1.2 \%$ $\mathrm{ZnSO}_{4} \cdot 7 \mathrm{H}_{2} \mathrm{O}+$ two foliar sprays @ $0.5 \% \mathrm{ZnSO}_{4} \cdot 7 \mathrm{H}_{2} \mathrm{O}$ and control were laid out in split plot design replicated thrice. The crop establishment methods did not show any significant influence on growth, yield and nutrient uptake by lentil. However, among the levels of $\mathrm{Zn}$ and methods of application, seed coating @ $1.8 \% \mathrm{ZnSO}_{4} \cdot 7 \mathrm{H}_{2} \mathrm{O}$ produced significantly taller plants, more leaf area index, dry matter accumulation and yield. Regarding $\mathrm{Zn}$ concentration, combination of seed coating and foliar application @ 1.2\% ZnSO $.7 \mathrm{H}_{2} \mathrm{O}+$ two foliar sprays @ 0.5\% $\mathrm{ZnSO}_{4} \cdot 7 \mathrm{H}_{2} \mathrm{O}$ resulted in significantly higher concentration than other treatments. $\mathrm{Zn}$ use efficiency was significantly higher (seed coating @ 1.2\% ZnSO $.7 \mathrm{H}_{2} \mathrm{O}$ for agronomic efficiency and physiological efficiency, seed coating @ $0.6 \% \mathrm{ZnSO}_{4} .7 \mathrm{H}_{2} \mathrm{O}$ for partial factor productivity and seed coating @ 1.8\% $\mathrm{ZnSO}_{4} .7 \mathrm{H}_{2} \mathrm{O}$ for apparent $\mathrm{Zn}$ recovery) as compared to that of foliar application or combined application of seed coating and foliar spray.
\end{abstract}

Keywords: Biofortification, lentil, Zn fertilization, nutrient uptake

\section{Introduction}

Zinc $(\mathrm{Zn})$ is one of the most important micronutrients for plant as well as animal body (Prasad, 2012; Prasad et al., 2014). The human body contains 2-3 g Zn and nearly $90 \%$ is found in muscle and bone (Wastney et al., 1986). Other organs containing estimable concentrations of $\mathrm{Zn}$ include prostate, liver, the gastrointestinal tract, kidney, skin, lung, brain, heart, and pancreas (Bentley et al., 1991; He et al., 1991; Llobet et al., 1988). At cellular level, $30-40 \%$ of $\mathrm{Zn}$ is localized in the nucleus, $50 \%$ in the cytosol and the remaining part is associated with membranes (Vallee and Falchuk, 1993).

Zn plays very important role in plant metabolism by influencing the activities of hydrogenase and carbonic anhydrase, stabilization of ribosomal fractions and synthesis of cytochrome (Tisdale et al., 1984). Plant enzymes activated by $\mathrm{Zn}$ are involved in carbohydrate metabolism,

Article History

RECEIVED on $02^{\text {nd }}$ September 2020 RECEIVED in revised form 20 th February 2021 ACCEPTED in final form $04^{\text {th }}$ April 2021 
maintenance of the integrity of cellular membranes, protein synthesis, and regulation of auxin synthesis and pollen formation (Marschner, 1995; Hafeez et al., 2013). The regulation and maintenance of the gene expression required for the tolerance of environmental stresses in plants are Zn dependent (Cakmak, 2000). Its deficiency results in the development of abnormalities in plants which become visible as deficiency symptoms such as stunted growth, chlorosis and smaller leaves, spikelet sterility. Zn deficiency can also adversely affect the quality of harvested products; plants susceptibility to injury by high light or temperature intensity and to infection by fungal diseases can also increase (Marschner, 1995, Cakmak, 2000). Zn seems to affect the capacity for water uptake and transport in plants and also reduce the adverse effects of short periods of heat and salt stress (Kasim, 2007; Disante et al., 2010; Peck et al., 2010; Tavallali et al., 2010). As $\mathrm{Zn}$ is required for the synthesis of tryptophan which is a precursor of IAA, it also has an active role in the production of an essential growth hormone auxin (Alloway et al., 2008). The $\mathrm{Zn}$ is required for integrity of cellular membranes to preserve the structural orientation of macromolecules and ion transport systems. Its interaction with phospholipids and sulphydryl groups of membrane proteins contributes for the maintenance of membranes (KabataPendias and Pendias, 2001; Dang et al., 2010). Zn is one of the most important micronutrients for many crop plants such as rice, maize and wheat, or soybean, which are being cultivated Worldwide (Preetha et al., 2014).

Pulses (food legumes), are an important source of protein in a vegetarian diet, especially in India, where a large population is vegetarian and protein malnutrition is rampant (Prasad, 2003; Prasad and Shivay, 2019). Further, pulses are also rich in $\mathrm{Zn}$ than cereals (Hemalatha et al., 2007). Globally, India is one of the largest producers and as well as consumers of the pulses. In India total area in pulses was $29.2 \mathrm{mha}$, production $22.1 \mathrm{mt}$ and average productivity $757 \mathrm{~kg} \mathrm{ha}^{-1}$ during 2018-19 (Anonymous, 2021). Application of $\mathrm{Zn}$ to the soil increased the grain weight, yield and harvest index in lentil (Oktem et al., 2019). Among legumes, chickpea responded well to $\mathrm{Zn}$ application and $\mathrm{Zn}$ biofortification is possible by $\mathrm{Zn}$ application (Shivay et al., 2014a). Application of $Z n$ sulfate to soils low in plant available $\mathrm{Zn}$ may show positive yield responses and also elevate grain $\mathrm{Zn}$ concentration to desired levels (Maqsood et al., 2016). Unlikely very few research works has been done on lentil emphasizing effective methods of $\mathrm{Zn}$ application for agronomic biofortification. Hence, this research was conducted with an objective to determine the most effective level and method of $\mathrm{Zn}$ application to improve growth, productivity and nutrient uptake and $\mathrm{Zn}$ use efficiency of lentil.

\section{Materials and Methods}

\subsection{Description of the study area}

The field experiments were conducted on lentil during rabi (October to March) seasons of 2016 and 2017 at the agricultural farm, Institute of Agriculture (Palli Siksha Bhavana), Visva-Bharati, Sriniketan, Birbhum, West Bengal, India on red and lateritic soil. The farm is situated at $23^{\circ} 39^{\prime} \mathrm{N}$ latitude and $87^{\circ} 42^{\prime} \mathrm{E}$ longitude with an average altitude of $58.90 \mathrm{~m}$ above mean sea level under sub-humid region of West Bengal. During cropping period of lentil, average temperature ranged from $13.8^{\circ} \mathrm{C}$ to $28.7^{\circ} \mathrm{C}$ in 2016 and $13.8^{\circ} \mathrm{C}$ to $27.4^{\circ} \mathrm{C}$ in 2017 . Average rainfall was negligible $(0.34 \mathrm{~mm}$ in 2016 and $1.34 \mathrm{~mm}$ in 2017) during both the years. The soil of the experimental field was sandy loam in texture, well drained with low level of organic carbon (0.39\%), available nitrogen and potassium (K) content and medium in available phosphorus ( $\mathrm{P}$ ) (Lambers and Barrow, 2020). The soil was slightly acidic (pH 5.5) in reaction (1:2.5 soil and water ratio). Diethylene tri-amine penta acetic acid (DTPA) extractable $\mathrm{Zn}$ in soil was 0.5 to $0.55 \mathrm{mg} \mathrm{kg}^{-1}$ of soil (Lindsay and Norvell, 1978).

\subsection{Experimental design and procedure}

The experiment was laid out in a split plot design consisting of two main plot treatments and seven sub-plot treatments replicated thrice. Two crop establishment methods (CEMs) were included in the main plot viz., zero tillage (ZT) and conventional tillage (CT). The sub-plot treatments consisted of different $\mathrm{Zn}$ levels and methods of their application i.e. control, seed coating @ 0.6\% ZnSO $.7 \mathrm{H}_{2} \mathrm{O}$, seed coating @ $1.2 \% \mathrm{ZnSO}_{4} .7 \mathrm{H}_{2} \mathrm{O}$, seed coating @ 1.8\% ZnSO $.7 \mathrm{H}_{2} \mathrm{O}$, twofoliar sprays @ 0.5\% ZnSO.7 $\mathrm{H}_{2} \mathrm{O}$, three-foliar sprays @ 0.5\% $\mathrm{ZnSO}_{4} .7 \mathrm{H}_{2} \mathrm{O}, 1.2 \% \mathrm{ZnSO}_{4} .7 \mathrm{H}_{2} \mathrm{O}$ seed coating+two-foliar sprays @ $0.5 \% \mathrm{ZnSO}_{4} .7 \mathrm{H}_{2} \mathrm{O}$.

Seed coating with $\mathrm{ZnSO}_{4} \cdot 7 \mathrm{H}_{2} \mathrm{O}$ was done one day before sowing and coated seeds were sown. For two foliar spray @ $0.5 \% \mathrm{ZnSO}_{4} .7 \mathrm{H}_{2} \mathrm{O}$, spraying was done during vegetative growth stage (at 30 DAS) and before flowering stage (at 50 DAS). For three foliar spray @ $0.5 \% \mathrm{ZnSO}_{4} .7 \mathrm{H}_{2} \mathrm{O}$, spraying was done during vegetative growth stage (at 30 DAS) and before flowering stage (at 50 DAS) and during pod development stage (80 DAS). Seed rate @ $30 \mathrm{~kg} \mathrm{ha}^{-1}$ (recommended after coating with $\mathrm{Zn}$ sulphate heptahydrate) was used following seed coating procedure. The $40 \mathrm{~g}$ gum acacia $\mathrm{kg}^{-1}$ of seed was added to ensure adequate adhesiveness in lentil seed. The $0.6 \% \mathrm{ZnSO}_{4} .7 \mathrm{H}_{2} \mathrm{O}$ coating required $180 \mathrm{~g} \mathrm{ZnSO} .7 \mathrm{H}_{2} \mathrm{O}$ which contained $37.8 \mathrm{~g} \mathrm{Zn}$. Thus, seed coating of $1.2 \% \mathrm{ZnSO}_{4} .7 \mathrm{H}_{2} \mathrm{O}$ contained $75.6 \mathrm{~g} \mathrm{Zn}$ per ha and seed coating of $1.8 \%$ $\mathrm{ZnSO}_{4} .7 \mathrm{H}_{2} \mathrm{O}$ contained $113.4 \mathrm{~g} \mathrm{Zn} \mathrm{ha}{ }^{-1}$. In case of foliar spray of lentil, $2.5 \mathrm{~kg} \mathrm{ZnSO}_{4} .7 \mathrm{H}_{2} \mathrm{O}$ was used for 500 litres of water ha-1. Likewise, $5 \mathrm{~kg}$ and $7.5 \mathrm{~kg}$ of $\mathrm{ZnSO}_{4} \cdot 7 \mathrm{H}_{2} \mathrm{O}$ were used for two- and three-times sprays per hectare. The recommended dose of N, P and K for lentil @ 30, 26.2 and $33.3 \mathrm{~kg} \mathrm{ha}^{-1}$ was applied as basal during land preparation. The $\mathrm{ZnSO}_{4} \cdot 7 \mathrm{H}_{2} \mathrm{O}$ contains $21 \% \mathrm{Zn}$.

Popular recommended lentil variety WBL 58 (Subrata) of 106 days duration was sown at $25 \times 10 \mathrm{~cm}^{2}$ spacing on the $3^{\text {rd }}$ November of both the years (2016 and 2017). Plant height, 
leaf area, dry weight of samples was recorded at 30 days after sowing (DAS), 60 DAS, 90 DAS and at harvest during both the years. Five plants from each plot for lentil were randomly selected and their heights were measured from ground level to top of the canopy with a wooden meter scale. The plant height was recorded at 30, 6090 DAS and at harvest period. For dry weight and leaf area, destructive samples were taken in each plot at an interval of 30 days starting from 30 DAS, i.e., at 30,60 and 90 DAS during rabi season. The sample was cut at ground level at 30,60 and 90 DAS. The green and senescenced leaves and stems were separated and dried in a hot-air oven at a temperature of $65 \pm 2^{\circ} \mathrm{C}$ for 72 hours till constant weight was recorded. Then total plant dry weight ( g plant $^{-1}$ ) was found out after summing of dry weight of different plant parts and dry matter accumulation in $\mathrm{g} \mathrm{m}^{-2}$ was worked out based on plant population density in different plots. The representative green leaves were taken randomly from each plot during destructive sampling at 30,60, and 90 DAS under study and their areas were recorded by leaf area meter. The leaves were then dried in a hot air oven at $65 \pm 2^{\circ} \mathrm{C}$ for 48 hours still constant weights were obtained and dry weights of leaves were taken with an electrical balance. The area/weight relationship was used to determine leaf area indices as described by Kemp (1960). Since, leaf area index (LAI) is area of leaf surface per unit land surface (Watson, 1952) and it was obtained by multiplying the area/weight ratio with the dry weight of green leaves obtained per unit of land area. Crop growth rate during 30 to 60,60 to 90 DAS and 90 DAS to harvest were determined with the help of following formula; $C G R=\left(W_{2}-W_{1}\right) /\left(t_{2}-t_{1}\right)$; Where, $w_{2}$ and $w_{1}$ are the final and initial total dry weights of all plant parts per unit land area $\left(\mathrm{m}^{2}\right)$ at the time $t_{2}$ and $t_{1}$, respectively and the unit was $\mathrm{g} \mathrm{m}^{-2}$ day $^{-1}$. Plant samples (grain and stover) collected at maturity during 2016 and 2017 were dried, grinded and used for chemical analysis. Zn content in the grain and stover of the crop was determined by atomic absorption spectrophotometer (AAS-4129) from the extract obtained through digestion with di-acid mixture and it was expressed in $\mathrm{mg} \mathrm{kg}^{-1}$. The experimental data were analysed following the standard statistical method (Panse and Sukhatme, 1985; Gomez and Gomez, 1984) at 0.5\% level of significance.

\subsection{Zn use efficiency indices}

Partial factor productivity (PFP), agronomic efficiency $(A E)$, recovery efficiency or apparent $Z n$ recovery $(R E)$, and physiological efficiency (PE) of applied $Z n$ were computed using the following expressions as suggested by Fageria and Baligar (2001) and Shivay et al. (2010):

$$
P F P=Y_{Z n} / Z n_{a}
$$

$A E=\left(Y_{Z n}-Y_{c}\right) / Z n_{a}$

$R E=\left[\left(U_{Z n}-U_{C}\right) / Z n_{a}\right] \times 100$

$P E=\left(Y_{Z n}-Y_{C}\right) /\left(U_{Z n}-U_{C}\right)$

where, $Y_{Z n}$ and $U_{Z n}$ refer to the grain yield $\left(\mathrm{kg} \mathrm{ha}^{-1}\right)$ and total $\mathrm{Zn}$ uptake $\left(\mathrm{kg} \mathrm{ha}^{-1}\right)$, respectively, of lentil in $\mathrm{Zn}$ applied plots; $Y_{\mathrm{C}}$ and $U_{C}$ refer to the grain yield $\left(\mathrm{kg} \mathrm{ha}^{-1}\right)$ and total $\mathrm{Zn}$ uptake $(\mathrm{kg}$ $\mathrm{ha}^{-1}$ ), respectively, of lentil in control (no $\mathrm{Zn}$ ) plots; $\mathrm{Zn}_{\mathrm{a}}$ refers to the $\mathrm{Zn}$ applied $\left(\mathrm{kg} \mathrm{ha}^{-1}\right)$.

\section{Results and Discussion}

\subsection{Growth parameters}

\subsubsection{Plant height}

Plant height of lentil was increased as crop growth proceeded up to its maturity (Table 1 ). The investigation on the pooled data revealed that the crop establishment methods did not show any significant influence on the plant height of lentil during all observations recorded i.e. at 30 DAS, 60 DAS, and 90 DAS and at harvest. However, in respect to $\mathrm{Zn}$ levels and methods of application, the treatments showed significant effect on plant height during the entire period of plant growth of lentil. Among the treatments regarding $\mathrm{Zn}$ levels and methods of application, the treatments seed coating of $1.8 \% \mathrm{ZnSO}_{4} .7 \mathrm{H}_{2} \mathrm{O}$ produced tallest plant. This treatment i.e. seed coating @ 1.8\% $\mathrm{ZnSO}_{4} .7 \mathrm{H}_{2} \mathrm{O}$ resulted significantly in higher plant height than all the other treatments at 30 DAS and at later stage i.e. at 90 DAS and at harvest, it was significantly higher than the treatments two foliar sprays @ 0.5\% $\mathrm{ZnSO}_{4} .7 \mathrm{H}_{2} \mathrm{O}$, seed coating @ 0.6\% $\mathrm{ZnSO}_{4} .7 \mathrm{H}_{2} \mathrm{O}$ and control. However, this treatment, seed coating @ 1.8\% $\mathrm{ZnSO}_{4} .7 \mathrm{H}_{2} \mathrm{O}$ proved statistically at par with seed coating @ $1.2 \% \mathrm{ZnSO}_{4} .7 \mathrm{H}_{2} \mathrm{O}+$ two foliar sprays @ $0.5 \% \mathrm{ZnSO}_{4} .7 \mathrm{H}_{2} \mathrm{O}$, seed coating @ 1.2\% ZnSO $.7 \mathrm{H}_{2} \mathrm{O}$ and three foliar sprays @ $0.5 \% \mathrm{ZnSO}_{4} \cdot 7 \mathrm{H}_{2} \mathrm{O}$ at $90 \mathrm{DAS}$ and at harvest. While comparing to seed coating treatment, seed coating @ 1.8\% $\mathrm{ZnSO}_{4} .7 \mathrm{H}_{2} \mathrm{O}$ was found significantly higher than the seed coating @ $0.6 \%$ $\mathrm{ZnSO}_{4} .7 \mathrm{H}_{2} \mathrm{O}$ during both the years; however seed coating @ $1.2 \% \mathrm{ZnSO}_{4} .7 \mathrm{H}_{2} \mathrm{O}$ proved statistically at par. In case of foliar spray also, the treatment with three foliar sprays @ $0.5 \%$ $\mathrm{ZnSO}_{4} .7 \mathrm{H}_{2} \mathrm{O}$ was recorded statistically non-significant with two foliar sprays @ 0.5\% $\mathrm{ZnSO}_{4} .7 \mathrm{H}_{2} \mathrm{O}$. On the other hand, the interaction on the crop establishment methods within $\mathrm{Zn}$ levels and methods of application and the interaction on the $\mathrm{Zn}$ levels and methods of application within crop establishment methods recorded statistically at par with each other in both the years at all observations. According to the findings of the present study, seed coating @ $1.8 \% \mathrm{ZnSO}_{4} .7 \mathrm{H}_{2} \mathrm{O}$ resulted in the highest influence on plant height followed by seed coating @ $1.2 \% \mathrm{ZnSO}_{4} .7 \mathrm{H}_{2} \mathrm{O}+$ two foliar sprays @ $0.5 \% \mathrm{ZnSO}_{4} .7 \mathrm{H}_{2} \mathrm{O}$ and seed coating @ 1.2\% $\mathrm{ZnSO}_{4} .7 \mathrm{H}_{2} \mathrm{O}$. Hence, our results indicated that, plant height was significantly higher in seed coated treatment than combined and foliar treatments. $\mathrm{Zn}$ application resulted in more vegetative growth (Singh et al., 1992), leading to higher plant height (Oktem, 2019).

\subsubsection{Leaf area index (LAI)}

Leaf area index of lentil was increased as crop grown upto 60 DAS and then a decreasing trend was observed towards its maturity (Table 1). The perusal of the data revealed that the crop establishment methods did not show any significant influence on the leaf area index of lentil during all observations 
Table 1: Effect of cultivation methods and zinc levels and their methods of application on plant height and leaf area index of lentil at different growth stages (pooled data)

\begin{tabular}{|c|c|c|c|c|c|c|c|}
\hline \multirow[t]{2}{*}{ Treatment } & \multicolumn{4}{|c|}{ Plant height $(\mathrm{cm})$} & \multicolumn{3}{|c|}{ Leaf Area Index } \\
\hline & 30 DAS & 60 DAS & 90 DAS & At Harvest & 30 DAS & 60 DAS & 90 DAS \\
\hline \multicolumn{8}{|l|}{ Crop establishment methods (CEMs) } \\
\hline Zero tillage (ZT) & 9.3 & 18.3 & 28.6 & 28.4 & 0.27 & 0.94 & 0.74 \\
\hline Conventional tillage (CT) & 8.7 & 18.4 & 29.1 & 29.1 & 0.25 & 0.96 & 0.76 \\
\hline SEm \pm & 0.18 & 0.78 & 1.08 & 1.00 & 0.01 & 0.02 & 0.03 \\
\hline $\mathrm{CD}(p=0.05)$ & NS & NS & NS & NS & NS & NS & NS \\
\hline \multicolumn{8}{|l|}{ Zinc levels and methods of application } \\
\hline Control & 8.2 & 15.4 & 25.6 & 25.4 & 0.24 & 0.87 & 0.67 \\
\hline Seed coating of $0.6 \% \mathrm{ZnSO}_{4} \cdot 7 \mathrm{H}_{2} \mathrm{O}$ & 9.0 & 18.1 & 27.5 & 27.4 & 0.26 & 0.94 & 0.71 \\
\hline Seed coating of $1.2 \% \mathrm{ZnSO}_{4} \cdot 7 \mathrm{H}_{2} \mathrm{O}$ & 9.3 & 18.5 & 30.6 & 30.5 & 0.27 & 0.99 & 0.79 \\
\hline Seed coating of $1.8 \% \mathrm{ZnSO}_{4} \cdot 7 \mathrm{H}_{2} \mathrm{O}$ & 11.0 & 21.8 & 31.3 & 31.3 & 0.29 & 1.01 & 0.81 \\
\hline Two foliar spray @ 0.5\% ZnSO $.7 \mathrm{H}_{2} \mathrm{O}$ & 8.1 & 15.9 & 27.6 & 27.4 & 0.24 & 0.91 & 0.74 \\
\hline Three foliar spray @ 0.5\% ZnSO $\mathrm{Zn}_{4} \cdot 7 \mathrm{H}_{2} \mathrm{O}$ & 8.1 & 19.4 & 28.5 & 28.3 & 0.24 & 0.96 & 0.76 \\
\hline $\begin{array}{l}1.2 \% \mathrm{ZnSO}_{4} \cdot 7 \mathrm{H}_{2} \mathrm{O} \text { seed coating+two foliar } \\
\text { spray @ } 0.5 \% \mathrm{ZnSO}_{4} \cdot 7 \mathrm{H}_{2} \mathrm{O}\end{array}$ & 9.2 & 19.7 & 31.1 & 31.1 & 0.28 & 1.03 & 0.83 \\
\hline SEm \pm & 0.26 & 0.75 & 1.19 & 1.21 & 0.01 & 0.03 & 0.03 \\
\hline $\mathrm{CD}(p=0.05)$ & 0.77 & 2.18 & 3.47 & 3.52 & 0.02 & 0.10 & 0.09 \\
\hline \multicolumn{8}{|l|}{ Interaction } \\
\hline \multicolumn{8}{|c|}{ Cultivation method within $\mathrm{Zn}$ levels and methods of application } \\
\hline SEm \pm & 0.46 & 1.59 & 2.35 & 2.29 & 0.01 & 0.06 & 0.06 \\
\hline $\mathrm{CD}(p=0.05)$ & NS & NS & NS & NS & NS & NS & NS \\
\hline \multicolumn{8}{|c|}{ Zn levels and methods of application within cultivation methods } \\
\hline SEm \pm & 0.37 & 1.06 & 1.68 & 1.70 & 0.01 & 0.05 & 0.05 \\
\hline $\mathrm{CD}(p=0.05)$ & NS & NS & NS & NS & NS & NS & NS \\
\hline
\end{tabular}

Note: Seed rate $30 \mathrm{~kg} \mathrm{ha}^{-1}$; Foliar spray of $0.5 \% \mathrm{ZnSO}_{4} \cdot 7 \mathrm{H}_{2} \mathrm{O} @ 500$ litres solution ha- ${ }^{-1}$

i.e. at 30 DAS, 60 DAS, and at 90 DAS. However, in respect to Zn levels and methods of application, the treatments showed significant impact on leaf area index during the entire period of plant growth of lentil in both the years of the field studies. In respect to $\mathrm{Zn}$ levels and methods of application also, at all observations, the treatments seed coating @ 1.8\% $\mathrm{ZnSO}_{4} \cdot 7 \mathrm{H}_{2} \mathrm{O}$ produced highest LAI at initial stage i.e. at 30 DAS which was significantly higher than the treatments three foliar sprays @ $0.5 \% \mathrm{ZnSO}_{4} \cdot 7 \mathrm{H}_{2} \mathrm{O}$, two foliar sprays @ $0.5 \% \mathrm{ZnSO}_{4} \cdot 7 \mathrm{H}_{2} \mathrm{O}$, seed coating @ $0.6 \% \mathrm{ZnSO}_{4} .7 \mathrm{H}_{2} \mathrm{O}$ and control. However, at 60 DAS and 90 DAS, seed coating @ 1.2\% $\mathrm{ZnSO}_{4} \cdot 7 \mathrm{H}_{2} \mathrm{O}+$ two foliar sprays @ $0.5 \% \mathrm{ZnSO}_{4} .7 \mathrm{H}_{2} \mathrm{O}$ resulted in the highest LAI, which showed significant variation with two foliar sprays @ $0.5 \% \mathrm{ZnSO}_{4} \cdot 7 \mathrm{H}_{2} \mathrm{O}$, seed coating @ $0.6 \% \mathrm{ZnSO}_{4} \cdot 7 \mathrm{H}_{2} \mathrm{O}$ and control. In spite of this, the treatment seed coating @ 1.2\% $\mathrm{ZnSO}_{4} .7 \mathrm{H}_{2} \mathrm{O}+$ two foliar sprays @ $0.5 \% \mathrm{ZnSO}_{4} .7 \mathrm{H}_{2} \mathrm{O}$ was at par with seed coating @ 1.8\% $\mathrm{ZnSO}_{4} .7 \mathrm{H}_{2} \mathrm{O}$. While comparing the seed coating treatments, seed coating @ 1.8\% $\mathrm{ZnSO}_{4} \cdot 7 \mathrm{H}_{2} \mathrm{O}$ was found significantly higher than the seed coating @ 0.6\% $\mathrm{ZnSO}_{4} \cdot 7 \mathrm{H}_{2} \mathrm{O}$ during both the years and seed coating @ 1.2\% $\mathrm{ZnSO}_{4} \cdot 7 \mathrm{H}_{2} \mathrm{O}$ proved statistically at par. In case of foliar spray also, the treatment with three foliar sprays @ 0.5\% $\mathrm{ZnSO}_{4} .7 \mathrm{H}_{2} \mathrm{O}$ was recorded statistically non-significant with two foliar sprays @ $0.5 \% \mathrm{ZnSO}_{4} \cdot 7 \mathrm{H}_{2} \mathrm{O}$. Seed coating with $\mathrm{Zn}$ improved the seedling growth (Khan et al., 2000) due to continuous supply of Zn. For growth of cascades (Cakmak, 2000; Palmer and Guerinot, 2009) and increase in auxin level in roots (Pandey et al., 2010). Mondal et al. (2011) studied the effect of foliar $\mathrm{Zn}$ application (0.1\%) on leaf area of mungbean and reported significantly higher leaf area plant ${ }^{-1}\left(497 \mathrm{~cm}^{2}\right)$ over control.

\subsubsection{Dry matter accumulation (DMA)}

There was an increasing trend was found regarding dry matter accumulation as crop growth proceeds up to its maturity (Table 2). The perusal of the data revealed that the crop establishment methods did not show any significant influence on the dry matter accumulation of lentil during 
Table 2: Effect of cultivation methods and zinc levels and their methods of application on dry matter accumulation and crop growth rate of lentil at different growth stages

\begin{tabular}{|c|c|c|c|c|c|c|c|}
\hline \multirow[t]{2}{*}{ Treatment } & \multicolumn{4}{|c|}{ Dry matter accumulation $\left(\mathrm{g} \mathrm{m}^{-2}\right)$} & \multicolumn{3}{|c|}{ Crop growth rate $\left(\mathrm{g} \mathrm{m}^{-2}\right.$ day $\left.^{-1}\right)$} \\
\hline & 30 DAS & 60 DAS & 90 DAS & $\begin{array}{c}\text { At } \\
\text { Harvest }\end{array}$ & $\begin{array}{c}30-60 \\
\text { DAS }\end{array}$ & $\begin{array}{c}60-90 \\
\text { DAS }\end{array}$ & $\begin{array}{c}90 \text { DAS - at } \\
\text { harvest }\end{array}$ \\
\hline \multicolumn{8}{|l|}{ Crop establishment methods (CEMs) } \\
\hline Zero tillage (ZT) & 19.1 & 117.4 & 295.0 & 314.9 & 3.28 & 5.92 & 0.66 \\
\hline Conventional tillage (CT) & 18.6 & 119.0 & 290.0 & 308.9 & 3.35 & 5.70 & 0.63 \\
\hline SEm \pm & 0.69 & 2.15 & 9.23 & 10.16 & 0.12 & 0.21 & 0.01 \\
\hline$C D(p=0.05)$ & NS & NS & NS & NS & NS & NS & NS \\
\hline \multicolumn{8}{|l|}{ Zinc levels and methods of application } \\
\hline Control $\left(Z n_{0}\right)$ & 18.0 & 114.2 & 279.3 & 294.2 & 3.21 & 5.51 & 0.50 \\
\hline Seed coating of $0.6 \% \mathrm{ZnSO}_{4} \cdot 7 \mathrm{H}_{2} \mathrm{O}$ & 19.3 & 116.9 & 286.2 & 308.6 & 3.25 & 5.64 & 0.75 \\
\hline Seed coating of $1.2 \% \mathrm{ZnSO}_{4} \cdot 7 \mathrm{H}_{2} \mathrm{O}$ & 19.2 & 120.3 & 288.4 & 318.1 & 3.37 & 5.61 & 0.99 \\
\hline Seed coating of $1.8 \% \mathrm{ZnSO}_{4} \cdot 7 \mathrm{H}_{2} \mathrm{O}$ & 20.0 & 121.3 & 290.8 & 332.2 & 3.38 & 5.65 & 1.38 \\
\hline Two foliar spray @ 0.5\% ZnSO ${ }_{4} \cdot 7 \mathrm{H}_{2} \mathrm{O}$ & 18.1 & 116.7 & 296.1 & 300.4 & 3.29 & 5.98 & 0.14 \\
\hline Three foliar spray @ 0.5\% ZnSO ${ }_{4} \cdot 7 \mathrm{H}_{2} \mathrm{O}$ & 17.9 & 117.2 & 300.1 & 305.9 & 3.31 & 6.10 & 0.20 \\
\hline $\begin{array}{l}1.2 \% \mathrm{ZnSO}_{4} \cdot 7 \mathrm{H}_{2} \mathrm{O} \text { seed coating+two foliar } \\
\text { spray @ } 0.5 \% \mathrm{ZnSO}_{4} \cdot 7 \mathrm{H}_{2} \mathrm{O}\left(\mathrm{Zn}_{6}\right)\end{array}$ & 19.3 & 121.2 & 306.5 & 324.0 & 3.40 & 6.18 & 0.58 \\
\hline SEm \pm & 1.17 & 1.43 & 5.72 & 8.49 & 0.14 & 0.16 & 0.01 \\
\hline $\operatorname{CD}(p=0.05)$ & NS & 4.18 & 16.70 & 24.78 & NS & 0.48 & 0.02 \\
\hline \multicolumn{8}{|l|}{ Interaction } \\
\hline \multicolumn{8}{|c|}{ Cultivation method within $\mathrm{Zn}$ levels and methods of application } \\
\hline SEm \pm & 1.95 & 3.87 & 16.26 & 19.62 & 0.27 & 0.39 & 0.01 \\
\hline $\mathrm{CD}(p=0.05)$ & NS & NS & NS & NS & NS & NS & NS \\
\hline \multicolumn{8}{|c|}{ Zn levels and methods of application within cultivation methods } \\
\hline SEm \pm & 1.65 & 2.03 & 8.09 & 12.01 & 0.19 & 0.23 & 0.01 \\
\hline$C D(p=0.05)$ & NS & NS & NS & NS & NS & NS & NS \\
\hline
\end{tabular}

Note: Seed rate $30 \mathrm{~kg} \mathrm{ha}^{-1}$; Foliar spray of $0.5 \% \mathrm{ZnSO}_{4} \cdot 7 \mathrm{H}_{2} \mathrm{O} @ 500$ litres solution ha-1

all observations i.e. at 30 DAS, 60 DAS, and at 90 DAS and at harvest. However, in respect to $\mathrm{Zn}$ levels and methods of application, the treatments showed significant effect on dry matter accumulation during the entire period of plant growth of lentil in both the years of the field studies. In respect to $\mathrm{Zn}$ levels and methods of application, except 90 DAS, at all observations, the treatments seed coating @ $1.8 \% \mathrm{ZnSO}_{4} .7 \mathrm{H}_{2} \mathrm{O}$ produced highest dry matter accumulation which was significantly higher than the treatments of three foliar sprays @ $0.5 \% \mathrm{ZnSO}_{4} \cdot 7 \mathrm{H}_{2} \mathrm{O}$, two foliar sprays @ $0.5 \%$ $\mathrm{ZnSO}_{4} \cdot 7 \mathrm{H}_{2} \mathrm{O}$, seed coating @ $0.6 \% \mathrm{ZnSO}_{4} \cdot 7 \mathrm{H}_{2} \mathrm{O}$ and control. In case of 90 DAS, the highest dry matter accumulation was recorded with seed coating @ 1.2\% $\mathrm{ZnSO}_{4} .7 \mathrm{H}_{2} \mathrm{O}+$ two foliar sprays @ $0.5 \% \mathrm{ZnSO}_{4} \cdot 7 \mathrm{H}_{2} \mathrm{O}$. Though this treatment proved significant difference with seed coating @ $0.6 \% \mathrm{ZnSO}_{4} \cdot 7 \mathrm{H}_{2} \mathrm{O}$, seed coating @ $1.2 \% \mathrm{ZnSO}_{4} \cdot 7 \mathrm{H}_{2} \mathrm{O}$ and control, however it was found statistically non-significant with the treatment seed coating @ 1.8\% $\mathrm{ZnSO}_{4} \cdot 7 \mathrm{H}_{2} \mathrm{O}$. While comparing to the seed coating treatments, seed coating @ 1.8\% $\mathrm{ZnSO}_{4} .7 \mathrm{H}_{2} \mathrm{O}$ was found statistically at par with seed coating @ $0.6 \% \mathrm{ZnSO}_{4} \cdot 7 \mathrm{H}_{2} \mathrm{O}$ and seed coating @ 1.2\% $\mathrm{ZnSO}_{4} \cdot 7 \mathrm{H}_{2} \mathrm{O}$. In case of foliar spray also, the treatment with three foliar sprays @ 0.5\% $\mathrm{ZnSO}_{4} .7 \mathrm{H}_{2} \mathrm{O}$ was observed statistically non-significant to two foliar sprays @ $0.5 \% \mathrm{ZnSO}_{4} .7 \mathrm{H}_{2} \mathrm{O}$. On the other hand, the interaction on the crop establishment methods within $\mathrm{Zn}$ levels and methods of application and the interaction on the $\mathrm{Zn}$ levels and methods of application within crop establishment methods recorded statistically at par with each other in both the years at all observations. Zn augments the auxin and its ample supply regulates the growth promotion (Alloway, 2008; Prasad et al., 2012). Almost the same trend was followed in case of leaf area index, dry matter accumulation, and crop growth rate. Thamke (2017) also studied the effect of graded levels of $\mathrm{Zn}$ on leaf area and growth parameters of pigeonpea and 
indicated significantly higher leaf area under application of 15 $\mathrm{kg} \mathrm{ZnSO}$ along with RDF. Due to having Zn application through seed coating the $\mathrm{Zn}$ particles were available in the rhizospheric zone and it was easily available to the plants during the seed germination. This $\mathrm{Zn}$ was used by the plant throughout its growth period. Basically, coating forms a nutrient layer in the vicinity of the emerging seedling, hence making the nutrient available during the initial phase of seedling growth (Taylor and Herman, 1990; Ozturk et al., 2006). For these reasons seed coated and the combined treatments showed better crop growth than foliar application alone.

\subsubsection{Crop growth rate (CGR)}

Crop growth rate of lentil was increased up to 60 DAS to 90 DAS and then a decreasing trend was observed as crop growth proceeds towards its maturity (Table 2 ). In respect to $\mathrm{Zn}$ levels and methods of application, at the stage of 30 DAS to 60 DAS the highest crop growth rate was observed in the treatment with seed coating @ 1.2\% ZnSO $4.7 \mathrm{H}_{2} \mathrm{O}+$ two foliar sprays @ 0.5\% ZnSO $.7 \mathrm{H}_{2} \mathrm{O}$ during 2016 and 2017, respectively. However, no significant variation was observed among the treatments at this stage. At the stage of 60 DAS to 90 DAS, the highest crop growth rate was observed in seed coating @ 1.2\% $\mathrm{ZnSO}_{4} .7 \mathrm{H}_{2} \mathrm{O}+$ two foliar sprays @ 0.5\% $\mathrm{ZnSO}_{4} .7 \mathrm{H}_{2} \mathrm{O}$ followed by three foliar sprays @ $0.5 \% \mathrm{ZnSO}_{4} .7 \mathrm{H}_{2} \mathrm{O}$ and at 90 DAS to harvest stage, seed coating @ 1.8\% $\mathrm{ZnSO}_{4} .7 \mathrm{H}_{2} \mathrm{O}$ showed the highest crop growth rate. Here, notable higher crop growth rate was observed during flowering to pod development stage. When comparing the seed coating treatments, seed coating @ $1.8 \% \mathrm{ZnSO}_{4} \cdot 7 \mathrm{H}_{2} \mathrm{O}$ was found significantly higher than the seed coating @ 0.6\% ZnSO $.7 \mathrm{H}_{2} \mathrm{O}$ during both the years; however seed coating @ 1.2\% ZnSO $4.7 \mathrm{H}_{2} \mathrm{O}$ proved statistically at par during 2016 and 2017. In case of foliar spray also, the treatment with three foliar sprays @ 0.5\% $\mathrm{ZnSO}_{4} .7 \mathrm{H}_{2} \mathrm{O}$ was recorded statistically non-significant to two foliar sprays @ $0.5 \% \mathrm{ZnSO}_{4} .7 \mathrm{H}_{2} \mathrm{O}$ in both the years. In this context, Puste and Jana (1988) found that application of $\mathrm{Zn}$ at $20 \mathrm{~kg} \mathrm{ZnSO}_{4} \mathrm{ha}^{-1}$ greatly influenced the leaf area index and crop growth rate of pigeonpea.

\subsection{Yield}

\subsubsection{Grain yield of lentil}

The perusal of the data revealed that the crop establishment methods did not show any significant impact on the grain yield (Table 3 ), while in respect to $\mathrm{Zn}$ levels and methods of application, the treatments showed significant effect on grain yield of lentil. The treatment with seed coating @ 1.8\% $\mathrm{ZnSO}_{4} .7 \mathrm{H}_{2} \mathrm{O}$ resulted in the highest grain yield $(1067.5 \mathrm{~kg}$ $\mathrm{ha}^{-1}$ ) of lentil which produced significantly $14 \%, 10 \%, 10.6 \%$ and $16.4 \%$ higher than the treatments of two foliar sprays @ $0.5 \% \mathrm{ZnSO}_{4} .7 \mathrm{H}_{2} \mathrm{O}$, three foliar sprays @ 0.5\% $\mathrm{ZnSO}_{4} .7 \mathrm{H}_{2} \mathrm{O}$, seed coating @ $0.6 \% \mathrm{ZnSO}_{4} .7 \mathrm{H}_{2} \mathrm{O}$ and control, respectively. However, this treatment with seed coating @ 1.8\% $\mathrm{ZnSO}_{4} .7 \mathrm{H}_{2} \mathrm{O}$ was statistically at par with seed coating @ 1.2\% ZnSO $4.7 \mathrm{H}_{2} \mathrm{O}+$ two foliar sprays @ 0.5\% $\mathrm{ZnSO}_{4} .7 \mathrm{H}_{2} \mathrm{O}$ and seed coating @ 1.2\%
$\mathrm{ZnSO}_{4} .7 \mathrm{H}_{2} \mathrm{O}$ though it produced $1.4 \%$ and $4.8 \%$ higher yield than those treatments, respectively. While comparing the seed coating treatments, seed coating @ 1.8\% ZnSO $.7 \mathrm{H}_{2} \mathrm{O}$ proved $10.6 \%$ higher grain yield than seed coating @ $0.6 \% \mathrm{ZnSO}_{4} .7 \mathrm{H}_{2} \mathrm{O}$ which showed significant difference. However, this treatment, seed coating @1.8\% ZnSO $.7 \mathrm{H}_{2} \mathrm{O}$ yielded 4.8\% higher grain yield than the treatment seed coating @ 1.2\% $\mathrm{ZnSO}_{4} .7 \mathrm{H}_{2} \mathrm{O}$ but they remained at par. However, in case of foliar spray, the treatment with three foliar sprays @ 0.5\% $\mathrm{ZnSO}_{4} .7 \mathrm{H}_{2} \mathrm{O}$ produced 3.5\% higher grain yield over two foliar sprays @ $0.5 \%$ $\mathrm{ZnSO}_{4} \cdot 7 \mathrm{H}_{2} \mathrm{O}$ and these treatments were at par with each other. On the other hand, the interaction on the crop establishment methods within $\mathrm{Zn}$ levels and methods of application and the interaction on the $\mathrm{Zn}$ levels and methods of application within crop establishment methods recorded statistically at par with each other in both the years. Hence, our results indicated that, grain yield was significantly higher in seed coated treatment than combined and foliar treatments. In this context, Islam et al. (2018) reported that any micronutrient deficiencies may result in yield loss, and this could be recovered if the relevant micronutrients are applied. However, Haider et al. (2018) indicated that foliar application of Zn considerably improved the mungbean growth, yield and yield related traits. Shivay et al. (2014b) reported Zn application in chickpea increased significantly the grain yield with successive increase in the doses of Zn. Our findings are in agreement with those reported earlier (Shivay et al., 2015).

\subsubsection{Stover yield of lentil}

The examination of the data revealed that the crop establishment methods did not show any significant effect on the stover yield (Table 3), while in respect to $\mathrm{Zn}$ levels and methods of application, the treatments showed significant effect on stover yield of lentil. The highest $\left(2254.5 \mathrm{~kg} \mathrm{ha}^{-1}\right)$ stover yield of lentil was recorded in the treatment with seed coating @ 1.8\% ZnSO $.7 \mathrm{H}_{2} \mathrm{O}$ which resulted significantly 9\%, $7.8 \%$ and $11.3 \%$ higher stover yield than the treatment having two foliar sprays @ 0.5\% ZnSO $.7 \mathrm{H}_{2} \mathrm{O}$, three foliar sprays @ $0.5 \% \mathrm{ZnSO}_{4} .7 \mathrm{H}_{2} \mathrm{O}$ and control. However, this treatment with seed coating @ 1.8\% ZnSO $.7 \mathrm{H}_{2} \mathrm{O}$ proved non-significant with the treatments, seed coating @ 1.2\% ZnSO $.7 \mathrm{H}_{2} \mathrm{O}+$ two foliar sprays @ 0.5\% $\mathrm{ZnSO}_{4} .7 \mathrm{H}_{2} \mathrm{O}$ and seed coating @ 1.2\% $\mathrm{ZnSO}_{4} .7 \mathrm{H}_{2} \mathrm{O}$ though it produced $3 \%$ and $4.3 \%$ higher stover yield than those treatments, respectively. While comparing the seed coating treatments, seed coating @ 1.8\% ZnSO $.7 \mathrm{H}_{2} \mathrm{O}$ was found non-significant with seed coating @ $0.6 \% \mathrm{ZnSO}_{4} .7 \mathrm{H}_{2} \mathrm{O}$ and seed coating @ 1.2\% $\mathrm{ZnSO}_{4} .7 \mathrm{H}_{2} \mathrm{O}$, however it produced $6.3 \%$ and $4.3 \%$ higher stover yield over those treatments, respectively. When comparing the seed coating treatments, seed coating @ 1.8\% ZnSO $.7 \mathrm{H}_{2} \mathrm{O}$ showed no significant difference, with seed coating @ 1.2\% ZnSO $.7 \mathrm{H}_{2} \mathrm{O}$ and seed coating @ 0.6\% ZnSO $.7 \mathrm{H}_{2} \mathrm{O}$. Although, seed coating @ 1.8\% $\mathrm{ZnSO}_{4} .7 \mathrm{H}_{2} \mathrm{O}$ produced $4.3 \%$ higher stover yield over seed coating @ 1.2\% ZnSO $.7 \mathrm{H}_{2} \mathrm{O}$ and 6.3\% higher stick yield over seed coating @ 0.6\% ZnSO $\mathrm{Zn}_{4} \cdot 7 \mathrm{H}_{2} \mathrm{O}$. However, in case of foliar 
Table 3: Effect of cultivation methods and zinc levels and their methods of application on yield, $\mathrm{Zn}$ concentration and $\mathrm{Zn}$ uptake of lentil

\begin{tabular}{|c|c|c|c|c|c|c|c|c|}
\hline \multirow[t]{2}{*}{ Treatment } & \multicolumn{3}{|c|}{ Yield } & \multicolumn{2}{|c|}{ Zn concentration } & \multicolumn{3}{|c|}{ Zn uptake } \\
\hline & $\begin{array}{c}\text { Grain } \\
\text { yield } \\
\left(\mathrm{kg} \mathrm{ha}^{-1}\right)\end{array}$ & $\begin{array}{l}\text { Stover } \\
\text { yield } \\
\left(\mathrm{kg} \mathrm{ha}^{-1}\right)\end{array}$ & $\begin{array}{l}\text { Harvest } \\
\text { index }\end{array}$ & $\begin{array}{c}\text { Grain } \mathrm{Zn} \\
\text { concentration } \\
\left(\mathrm{mg} \mathrm{kg}^{-1}\right)\end{array}$ & $\begin{array}{c}\text { Stover } \mathrm{Zn} \\
\text { concentration } \\
\left(\mathrm{mg} \mathrm{kg}^{-1}\right)\end{array}$ & $\begin{array}{l}\text { Grain } \\
\text { uptake } \\
\left(\mathrm{g} \mathrm{ha}^{-1}\right)\end{array}$ & $\begin{array}{l}\text { Stover } \\
\text { uptake } \\
\left(\mathrm{g} \mathrm{ha}^{-1}\right)\end{array}$ & $\begin{array}{l}\text { Total } \\
\text { uptake } \\
\left(\mathrm{g} \mathrm{ha}^{-1}\right)\end{array}$ \\
\hline \multicolumn{9}{|l|}{ Crop establishment methods (CEMs) } \\
\hline Zero tillage (ZT) & 979.5 & 2104.4 & 0.27 & 36.7 & 29.4 & 36.0 & 61.9 & 97.9 \\
\hline Conventional tillage (CT) & 999.5 & 2154.4 & 0.37 & 39.4 & 32.3 & 39.5 & 69.6 & 109.1 \\
\hline SEm \pm & 38.87 & 58.96 & 0.02 & 1.39 & 1.19 & 1.35 & 3.10 & 4.42 \\
\hline $\mathrm{CD}(p=0.05)$ & NS & NS & NS & NS & NS & NS & NS & NS \\
\hline \multicolumn{9}{|c|}{ Zinc levels and methods of application } \\
\hline Control $\left(Z n_{0}\right)$ & 917.0 & 2025.0 & 0.31 & 34.9 & 28.2 & 32.0 & 57.1 & 89.1 \\
\hline Seed coating of $0.6 \% \mathrm{ZnSO}_{4} \cdot 7 \mathrm{H}_{2} \mathrm{O}$ & 965.0 & 2120.5 & 0.31 & 35.7 & 29.0 & 34.5 & 61.5 & 96.0 \\
\hline Seed coating of $1.2 \% \mathrm{ZnSO}_{4} \cdot 7 \mathrm{H}_{2} \mathrm{O}$ & 1019.0 & 2161.5 & 0.32 & 36.9 & 29.9 & 37.6 & 64.6 & 102.2 \\
\hline Seed coating of $1.8 \% \mathrm{ZnSO}_{4} \cdot 7 \mathrm{H}_{2} \mathrm{O}$ & 1067.5 & 2254.5 & 0.32 & 37.8 & 30.9 & 40.3 & 69.7 & 110.0 \\
\hline $\begin{array}{l}\text { Two foliar spray @ 0.5\% } \\
\mathrm{ZnSO}_{4} \cdot 7 \mathrm{H}_{2} \mathrm{O}\end{array}$ & 936.5 & 2067.0 & 0.31 & 39.2 & 31.8 & 36.7 & 65.7 & 102.3 \\
\hline $\begin{array}{l}\text { Three foliar spray @ 0.5\% } \\
\mathrm{ZnSO}_{4} \cdot 7 \mathrm{H}_{2} \mathrm{O}\end{array}$ & 969.5 & 2089.5 & 0.32 & 40.1 & 32.6 & 38.9 & 68.0 & 106.9 \\
\hline $\begin{array}{l}1.2 \% \mathrm{ZnSO}_{4} \cdot 7 \mathrm{H}_{2} \mathrm{O} \text { seed coating+ } \\
\text { two foliar spray @ } 0.5 \% \\
\mathrm{ZnSO}_{4} \cdot 7 \mathrm{H}_{2} \mathrm{O}\end{array}$ & 1052.0 & 2188.0 & 0.32 & 42.1 & 33.6 & 44.3 & 73.4 & 117.7 \\
\hline SEm \pm & 31.83 & 49.02 & 0.01 & 1.39 & 1.17 & 1.54 & 2.34 & 3.84 \\
\hline $\mathrm{CD}(p=0.05)$ & 92.89 & 143.06 & NS & 4.06 & 3.41 & 4.49 & 6.83 & 11.20 \\
\hline \multicolumn{9}{|l|}{ Interaction } \\
\hline \multicolumn{9}{|c|}{ Cultivation method within Zn levels and methods of application } \\
\hline SEm \pm & 74.51 & 113.66 & 0.03 & 2.90 & 2.45 & 3.00 & 5.78 & 8.66 \\
\hline $\mathrm{CD}(p=0.05)$ & NS & NS & NS & NS & NS & NS & NS & NS \\
\hline \multicolumn{9}{|c|}{ Zn levels and methods of application within cultivation methods } \\
\hline SEm \pm & 45.01 & 69.32 & 0.02 & 1.97 & 1.65 & 2.18 & 3.31 & 5.43 \\
\hline $\mathrm{CD}(p=0.05)$ & NS & NS & NS & NS & NS & NS & NS & NS \\
\hline
\end{tabular}

Note: Seed rate $30 \mathrm{~kg} \mathrm{ha}^{-1}$; Foliar spray of $0.5 \% \mathrm{ZnSO}_{4} \cdot 7 \mathrm{H}_{2} \mathrm{O} @ 500$ litres solution ha-1

spray, application of three foliar sprays @ 0.5\% $\mathrm{ZnSO}_{4} .7 \mathrm{H}_{2} \mathrm{O}$ produced $1 \%$ higher stover yield over two foliar sprays @ $0.5 \% \mathrm{ZnSO}_{4} .7 \mathrm{H}_{2} \mathrm{O}$ and no significant difference was observed between them. On the other hand, the interaction on the crop establishment methods within $\mathrm{Zn}$ levels and methods of application and the interaction on the $\mathrm{Zn}$ levels and methods of application within crop establishment methods recorded statistically at par with each other in both the years. Hence, our results indicated that, stover yield was significantly higher in seed coated treatment than combined and foliar treatments. Increase in biological yield may be due to optimum dose of $\mathrm{Zn}$ sulphate which significantly enhanced straw and grain yield in chick pea (Montenegro et al., 2010; Usman et al., 2014;
Shivay et al., 2015) or in other pulse crop. On the other hand, seed coating produced the highest grain and biological yield over soil and foliar application (Farooq et al., 2018) because, fertilization by $\mathrm{Zn}$ containing fertilizer through soil application or seed coating provide availability of rhizospheric Zn (Kabir et al., 2014).

\subsubsection{Harvest index}

The perusal of the data revealed that the crop establishment methods as well as $\mathrm{Zn}$ levels and methods of application did not show any significant impact on harvest index of lentil (Table 3). The treatments, seed coating @ 1.2\% $\mathrm{ZnSO}_{4} \cdot 7 \mathrm{H}_{2} \mathrm{O}+$ two foliar sprays @ $0.5 \% \mathrm{ZnSO}_{4} \cdot 7 \mathrm{H}_{2} \mathrm{O}$, three foliar 
sprays @ 0.5\% ZnSO .7 $\mathrm{H}_{2} \mathrm{O}$, seed coating @ 1.8\% $\mathrm{ZnSO}_{4} .7 \mathrm{H}_{2} \mathrm{O}$ and seed coating @1.2\% $\mathrm{ZnSO}_{4} .7 \mathrm{H}_{2} \mathrm{O}$ resulted in the highest harvest index of lentil. However, these treatments were nonsignificant with each other. Application of seed coating $1.8 \%$ $\mathrm{ZnSO}_{4} .7 \mathrm{H}_{2} \mathrm{O}$ was found statistically at par with seed coating @ $0.6 \% \mathrm{ZnSO}_{4} .7 \mathrm{H}_{2} \mathrm{O}$ and seed coating @ 1.2\% ZnSO $.7 \mathrm{H}_{2} \mathrm{O}$. However, in case of foliar spray also, the treatment with three foliar sprays @ $0.5 \% \mathrm{ZnSO}_{4} .7 \mathrm{H}_{2} \mathrm{O}$ was recorded statistically non-significant to foliar spray of two foliar sprays @ $0.5 \%$ $\mathrm{ZnSO}_{4} .7 \mathrm{H}_{2} \mathrm{O}$. On the other hand, the interaction on the crop establishment methods within $\mathrm{Zn}$ levels and methods of application and the interaction on the $\mathrm{Zn}$ levels and methods of application within crop establishment methods recorded at par harvest index in both the years.

\subsection{Zinc concentration}

The perusal of the data revealed that the crop establishment methods did not show any significant effect on the grain $\mathrm{Zn}$ concentration of lentil (Table 3); while in respect to $\mathrm{Zn}$ levels and methods of application, the treatments produced significant differences regarding grain $\mathrm{Zn}$ concentration of lentil. The treatment with seed coating @ 1.2\% ZnSO $.7 \mathrm{H}_{2} \mathrm{O}+$ two foliar sprays@0.5\% $\mathrm{ZnSO}_{4} .7 \mathrm{H}_{2} \mathrm{O}$ resulted in the highest grain $\mathrm{Zn}$ concentration of lentil which showed significant difference with the treatment seed coating @1.8\% ZnSO $.7 \mathrm{H}_{2} \mathrm{O}$, seed coating @ 1.2\% ZnSO $.7 \mathrm{H}_{2} \mathrm{O}$, seed coating @ 0.6\% $\mathrm{ZnSO}_{4} .7 \mathrm{H}_{2} \mathrm{O}$ and control. However, this treatment with seed coating @ $1.2 \% \mathrm{ZnSO}_{4} .7 \mathrm{H}_{2} \mathrm{O}+$ two foliar sprays @ 0.5\% $\mathrm{ZnSO}_{4} .7 \mathrm{H}_{2} \mathrm{O}$ was statistically at par with three foliar sprays @ $0.5 \% \mathrm{ZnSO}_{4} .7 \mathrm{H}_{2} \mathrm{O}$ and two foliar sprays @ 0.5\% ZnSO $\mathrm{Zn}_{4} .7 \mathrm{H}_{2} \mathrm{O}$. When comparing seed coating treatments, seed coating @ 1.8\% ZnSO $\mathrm{Zn}_{4} \mathrm{O} \mathrm{O}$ was found statistically at par with seed coating @ $0.6 \% \mathrm{ZnSO}_{4} .7 \mathrm{H}_{2} \mathrm{O}$ and seed coating @ 1.2\% $\mathrm{ZnSO}_{4} .7 \mathrm{H}_{2} \mathrm{O}$. However, in case of foliar spray also, the treatment with three foliar sprays @ 0.5\% $\mathrm{ZnSO}_{4} .7 \mathrm{H}_{2} \mathrm{O}$ recorded statistically non-significant to two foliar sprays @ $0.5 \% \mathrm{ZnSO}_{4} .7 \mathrm{H}_{2} \mathrm{O}$. On the other hand, the interaction on the crop establishment methods within $\mathrm{Zn}$ levels and methods of application and the interaction on the $\mathrm{Zn}$ levels and methods of application within crop establishment methods recorded statistically at par with each other in both the years.

The perusal of the data revealed that the crop establishment methods did not show any significant effect on the stover $\mathrm{Zn}$ concentration (Table 3 ) of lentil, while in respect to $\mathrm{Zn}$ levels and methods of application, the treatments produced significant differences regarding stover $\mathrm{Zn}$ concentration of lentil. Application of seed coating @ 1.2\% ZnSO $.7 \mathrm{H}_{2} \mathrm{O}+$ two foliar sprays @ $0.5 \% \mathrm{ZnSO}_{4} .7 \mathrm{H}_{2} \mathrm{O}$ resulted into the highest stover $\mathrm{Zn}$ concentration of lentil which showed significant differences with the treatment seed coating @ 1.2\% ZnSO $4.7 \mathrm{H}_{2} \mathrm{O}$, seed coating @ $0.6 \% \mathrm{ZnSO}_{4} .7 \mathrm{H}_{2} \mathrm{O}$ and control. However, this treatment with seed coating @ 1.2\% $\mathrm{ZnSO}_{4} .7 \mathrm{H}_{2} \mathrm{O}+$ two foliar sprays @ 0.5\% ZnSO $.7 \mathrm{H}_{2} \mathrm{O}$ was statistically at par with three foliar sprays @ 0.5\% ZnSO $.7 \mathrm{H}_{2} \mathrm{O}$, two foliar sprays @ $0.5 \%$ $\mathrm{ZnSO}_{4} .7 \mathrm{H}_{2} \mathrm{O}$ and seed coating @ 1.8\% ZnSO $.7 \mathrm{H}_{2} \mathrm{O}$. While comparing the seed coating treatments, seed coating @ 1.8\%
$\mathrm{ZnSO}_{4} \cdot 7 \mathrm{H}_{2} \mathrm{O}$ was found statistically at par with seed coating @ $0.6 \% \mathrm{ZnSO}_{4} .7 \mathrm{H}_{2} \mathrm{O}$ and seed coating @ 1.2\% $\mathrm{ZnSO}_{4} .7 \mathrm{H}_{2} \mathrm{O}$ during 2016 and 2017, respectively. However, in case of foliar spray also, the treatment with three foliar sprays @ $0.5 \%$ $\mathrm{ZnSO}_{4} .7 \mathrm{H}_{2} \mathrm{O}$ was recorded statistically non-significant to two foliar sprays @ 0.5\% ZnSO $.7 \mathrm{H}_{2} \mathrm{O}$ during both the years. On the other hand, the interaction on the crop establishment methods within $\mathrm{Zn}$ levels and methods of application and the interaction on the $\mathrm{Zn}$ levels and methods of application within crop establishment methods recorded statistically at par with each other in both the years.

So, as per the results obtained, grain $\mathrm{Zn}$ concentration and stover $\mathrm{Zn}$ concentration was recorded highest in seed coating @ 1.2\% $\mathrm{ZnSO}_{4} .7 \mathrm{H}_{2} \mathrm{O}+$ two foliar sprays @ $0.5 \% \mathrm{ZnSO}_{4} .7 \mathrm{H}_{2} \mathrm{O}$. Interestingly, stover $\mathrm{Zn}$ concentration was recorded lower than grain $\mathrm{Zn}$ concentration. In the field study, combined application of both foliar and seed coating recorded higher grain and stover $\mathrm{Zn}$ concentration than the foliar applied treatments and seed coated treatments. Foliar $\mathrm{Zn}$ spray improved $\mathrm{Zn}$ concentration of the new growth formed after foliar spraying which shows that $\mathrm{Zn}$ in phloem is mobile and moved from treated leaves into youngest new leaves (Phuphong et al., 2020). More distinct increases in grain Zn by foliar $\mathrm{Zn}$ application were achieved when $\mathrm{Zn}$ was applied after flowering time, e.g., at early milk plus dough stages (Zhang et al., 2012).

\subsection{Zinc uptake}

The perusal of the data revealed that the crop establishment methods did not show any significant effect on the grain $\mathrm{Zn}$ uptake (Table 3 ) of lentil; while in respect to $\mathrm{Zn}$ levels and methods of application, the treatments produced significant differences with regard to grain $\mathrm{Zn}$ uptake of lentil. The treatment with seed coating @ 1.2\% ZnSO $.7 \mathrm{H}_{2} \mathrm{O}+$ two foliar sprays@0.5\% ZnSO $.7 \mathrm{H}_{2} \mathrm{O}$ resulted in the highest grain $\mathrm{Zn}$ uptake of lentil followed by seed coating @ $1.8 \%$ $\mathrm{ZnSO}_{4} .7 \mathrm{H}_{2} \mathrm{O}$ and three foliar sprays @ 0.5\% $\mathrm{ZnSO}_{4} .7 \mathrm{H}_{2} \mathrm{O}$. This treatment of seed coating @ 1.2\% ZnSO $.7 \mathrm{H}_{2} \mathrm{O}+$ two foliar sprays @ 0.5\% ZnSO $.7 \mathrm{H}_{2} \mathrm{O}$ showed significant differences with all other treatments. When comparing the seed coating treatments, seed coating @ 1.8\% $\mathrm{ZnSO}_{4} .7 \mathrm{H}_{2} \mathrm{O}$ was found significantly differed with seed coating @ $0.6 \% \mathrm{ZnSO}_{4} .7 \mathrm{H}_{2} \mathrm{O}$; however, it remained statistically at par with seed coating @ $1.2 \% \mathrm{ZnSO}_{4} .7 \mathrm{H}_{2} \mathrm{O}$. In case of foliar spray also, the treatment with three foliar sprays @ $0.5 \% \mathrm{ZnSO}_{4} .7 \mathrm{H}_{2} \mathrm{O}$ was recorded statistically non-significant with two foliar sprays @ $0.5 \%$ $\mathrm{ZnSO}_{4} .7 \mathrm{H}_{2} \mathrm{O}$ during 2016 and 2017, respectively. On the other hand, the interaction on the crop establishment methods within $\mathrm{Zn}$ levels and methods of application and the interaction on the $\mathrm{Zn}$ levels and methods of application within crop establishment methods recorded statistically at par with each other in both the years.

The perusal of the data revealed that the crop establishment methods did not show any significant effect on the stover $\mathrm{Zn}$ uptake (Table 3 ) of lentil, while in respect to $\mathrm{Zn}$ levels and 
methods of application, the treatments produced significant difference regarding stover $\mathrm{Zn}$ uptake of lentil. Application of seed coating @1.2\% ZnSO $.7 \mathrm{H}_{2} \mathrm{O}+$ two foliar sprays @ $0.5 \% \mathrm{ZnSO}_{4} \cdot 7 \mathrm{H}_{2} \mathrm{O}$ resulted in the highest stover $\mathrm{Zn}$ uptake of lentil, which showed significant difference with application of two foliar sprays @ 0.5\% $\mathrm{ZnSO}_{4} .7 \mathrm{H}_{2} \mathrm{O}$, seed coating @ $1.2 \% \mathrm{ZnSO}_{4} \cdot 7 \mathrm{H}_{2} \mathrm{O}$, seed coating @ $0.6 \% \mathrm{ZnSO}_{4} \cdot 7 \mathrm{H}_{2} \mathrm{O}$ and control. However, this treatment with seed coating @ 1.2\% $\mathrm{ZnSO}_{4} \cdot 7 \mathrm{H}_{2} \mathrm{O}+$ two foliar sprays @ $0.5 \% \mathrm{ZnSO}_{4} \cdot 7 \mathrm{H}_{2} \mathrm{O}$ was statistically at par with seed coating @ $1.8 \% \mathrm{ZnSO}_{4} \cdot 7 \mathrm{H}_{2} \mathrm{O}$ and three foliar sprays @ $0.5 \% \mathrm{ZnSO}_{4} .7 \mathrm{H}_{2} \mathrm{O}$. While comparing the seed coating treatments, seed coating @ $1.8 \% \mathrm{ZnSO}_{4} \cdot 7 \mathrm{H}_{2} \mathrm{O}$ was found statistically at par with seed coating @ $0.6 \% \mathrm{ZnSO}_{4} .7 \mathrm{H}_{2} \mathrm{O}$ and it was statistically at par with seed coating @ $1.2 \%$ $\mathrm{ZnSO}_{4} \cdot 7 \mathrm{H}_{2} \mathrm{O}$. However, in case of foliar spray, the treatment with three foliar sprays @ $0.5 \% \mathrm{ZnSO}_{4} .7 \mathrm{H}_{2} \mathrm{O}$ was found nonsignificant with two foliar sprays @ $0.5 \% \mathrm{ZnSO}_{4} \cdot 7 \mathrm{H}_{2} \mathrm{O}$. On the other hand, the interaction on the crop establishment methods within $\mathrm{Zn}$ levels and methods of application and the interaction on the $\mathrm{Zn}$ levels and methods of application within crop establishment methods recorded statistically at par with each other in both the years.

The perusal of the data revealed that the crop establishment methods did not show any significant effect on the total $\mathrm{Zn}$ uptake (Table 3) of lentil; while in respect to $\mathrm{Zn}$ levels and methods of application, the treatments produced significant difference regarding total $\mathrm{Zn}$ uptake by lentil. Application of seed coating @1.2\% ZnSO $.7 \mathrm{H}_{2} \mathrm{O}+$ two foliar sprays @ $0.5 \% \mathrm{ZnSO}_{4} .7 \mathrm{H}_{2} \mathrm{O}$ resulted in the highest total $\mathrm{Zn}$ uptake by lentil which showed significant differences with application of two foliar sprays @ 0.5\% ZnSO $.7 \mathrm{H}_{2} \mathrm{O}$, seed coating @ $1.2 \% \mathrm{ZnSO}_{4} \cdot 7 \mathrm{H}_{2} \mathrm{O}$, seed coating @ $0.6 \% \mathrm{ZnSO}_{4} \cdot 7 \mathrm{H}_{2} \mathrm{O}$ and control. However, this treatment with seed coating @ 1.2\% $\mathrm{ZnSO}_{4} .7 \mathrm{H}_{2} \mathrm{O}+$ two foliar sprays @ $0.5 \% \mathrm{ZnSO}_{4} .7 \mathrm{H}_{2} \mathrm{O}$ was statistically at par with seed coating @ $1.8 \% \mathrm{ZnSO}_{4} \cdot 7 \mathrm{H}_{2} \mathrm{O}$ and three foliar sprays @ $0.5 \% \mathrm{ZnSO}_{4} \cdot 7 \mathrm{H}_{2} \mathrm{O}$. When comparing the seed coating treatments, seed coating @ $1.8 \% \mathrm{ZnSO}_{4} \cdot 7 \mathrm{H}_{2} \mathrm{O}$ was found statistically at par with seed coating @ $0.6 \% \mathrm{ZnSO}_{4} .7 \mathrm{H}_{2} \mathrm{O}$ and it remained statistically at par with seed coating @ 1.2\% $\mathrm{ZnSO}_{4} \cdot 7 \mathrm{H}_{2} \mathrm{O}$. However, in case of foliar spray, application of three foliar sprays @ $0.5 \% \mathrm{ZnSO}_{4} .7 \mathrm{H}_{2} \mathrm{O}$ was found nonsignificant with two foliar sprays @ $0.5 \% \mathrm{ZnSO}_{4} \cdot 7 \mathrm{H}_{2} \mathrm{O}$. On the other hand, the interaction on the crop establishment methods within $\mathrm{Zn}$ levels and methods of application and the interaction on the $\mathrm{Zn}$ levels and methods of application within crop establishment methods recorded statistically at par with each other in both the years.

So, from the above mentioned of analysed data, it has been seen that grain $\mathrm{Zn}$ uptake and stover $\mathrm{Zn}$ uptake has been markedly influenced by various levels of $Z n$ and methods of application. According to the results, grain $\mathrm{Zn}$ uptake and stover $\mathrm{Zn}$ uptake was recorded highest with application of seed coating @ 1.2\% $\mathrm{ZnSO}_{4} .7 \mathrm{H}_{2} \mathrm{O}+$ two foliar sprays @ 0.5\% $\mathrm{ZnSO}_{4} \cdot 7 \mathrm{H}_{2} \mathrm{O}$. In the field study, combined application of both foliar and seed coating recorded higher grain and stover $\mathrm{Zn}$ uptake than the foliar applied treatments and seed coated treatments alone. This might be due to effects of seed $\mathrm{Zn}$ coating on seedling vigour and viability (Prom-u-thai et al., 2012) and further the remobilization of $\mathrm{Zn}$ from vegetative parts via phloem to developing grain after foliar spraying (Khampuang et al., 2020).

\subsection{Zinc use efficiency indices}

Zn use-efficiency indices in lentil crop were quantified in terms of partial factor productivity (PFP), agronomic efficiency $(A E)$, apparent $Z n$ recovery or recovery efficiency (RE), and physiological efficiency (PE) (Table 4). The data on the effect of different crop establishment methods and $\mathrm{Zn}$ levels and their methods of application on $\mathrm{Zn}$ use efficiency indices in lentil are depicted in Table 4.

The perusal of the data revealed that the crop establishment methods did not show any significant influence on $A E$ of $Z n$ in lentil. However, in respect to $\mathrm{Zn}$ levels and methods of application the treatments showed significant influence on $A E$ in lentil. A widely varied range (18.6-1349.2 kg grain increase per $\mathrm{kg} Z \mathrm{n}$ applied) was seen among the treatments with regard to $A E$ of $Z n$ in lentil. The highest $A E$ was obtained from seed coating @ $1.2 \% \mathrm{ZnSO}_{4} .7 \mathrm{H}_{2} \mathrm{O}$ which was significantly higher than other treatments. A decreasing trend was observed in $A E$ with the increase in applied $Z n$. On the other hand, seed coated treatments showed higher AE than foliar applied treatments as well as combined treatment (seed coating @ $1.2 \% \mathrm{ZnSO}_{4} \cdot 7 \mathrm{H}_{2} \mathrm{O}+$ two foliar sprays @ $0.5 \% \mathrm{ZnSO}_{4} \cdot 7 \mathrm{H}_{2} \mathrm{O}$ ).

The inspection of the data revealed that the crop establishment methods did not show any significant influence on PFP of $\mathrm{Zn}$ in lentil. However, with respect to $\mathrm{Zn}$ levels and methods of application the treatments showed significant influence on PFP of $Z n$ in lentil. A widely varied range (609.1-25529.1 kg grain yield per kg $Z n$ applied) was seen among the treatments with regard to PFP of $\mathrm{Zn}$ in lentil. The highest PFP was obtained from seed coating @ $0.6 \% \mathrm{ZnSO}_{4} .7 \mathrm{H}_{2} \mathrm{O}$ which was significantly higher than other treatments. A decreasing trend was observed in PFP with the increase in applied Zn. Besides regarding PFP, seed coated treatments showed higher results than both foliar and combined treatment (seed coating @ $1.2 \% \mathrm{ZnSO}_{4} \cdot 7 \mathrm{H}_{2} \mathrm{O}+$ two foliar sprays @ $\left.0.5 \% \mathrm{ZnSO}_{4} \cdot 7 \mathrm{H}_{2} \mathrm{O}\right)$.

The perusal of the data revealed that the crop establishment methods did not show any significant influence on RE of zinc in lentil. However, in respect to $\mathrm{Zn}$ levels and methods of application the treatments showed significant influence on RE of $\mathrm{Zn}$ in lentil. A wide variation (1.1-18.4\% to) was recorded among the treatments with regard to RE of $\mathrm{Zn}$ by lentil. The highest RE was obtained with application of seed coating @ $1.8 \% \mathrm{ZnSO}_{4} .7 \mathrm{H}_{2} \mathrm{O}$ which was significantly higher than other treatments. Seed coated treatments showed higher RE than foliar applied treatments and as well as combined treatment (seed coating @ 1.2\% $\mathrm{ZnSO}_{4} .7 \mathrm{H}_{2} \mathrm{O}+$ two foliar sprays @ 0.5\% $\left.\mathrm{ZnSO}_{4} .7 \mathrm{H}_{2} \mathrm{O}\right)$. 


\begin{tabular}{|c|c|c|c|c|c|}
\hline \multirow[t]{2}{*}{ Treatment } & \multirow{2}{*}{$\begin{array}{l}\text { Applied } \\
\text { zinc } \\
\left(\mathrm{kg} \mathrm{ha}^{-1}\right)\end{array}$} & \multicolumn{4}{|c|}{ Zinc use efficiency indices } \\
\hline & & $\begin{array}{c}\text { Agronomic } \\
\text { efficiency } \\
\text { (kg grain increase } \\
\mathrm{kg}^{-1} \mathrm{Zn} \text { applied) }\end{array}$ & $\begin{array}{l}\text { Partial factor } \\
\text { productivity } \\
\text { (kg grain yield } \\
\left.\mathrm{kg}^{-1} \mathrm{Zn}\right)\end{array}$ & $\begin{array}{l}\text { Apparent } \\
\text { Zn } \\
\text { recovery } \\
(\%)\end{array}$ & $\begin{array}{c}\text { Physiological } \\
\text { efficiency } \\
\text { (kg grain increase } \\
\mathrm{kg}^{-1} \mathrm{Zn} \text { uptake) }\end{array}$ \\
\hline \multicolumn{6}{|l|}{ Crop establishment methods (CEMs) } \\
\hline Zero tillage (ZT) & & 588.2 & 7192.6 & 8.1 & 4581.1 \\
\hline Conventional tillage (CT) & & 588.2 & 7338.2 & 8.7 & 4331.7 \\
\hline SEm \pm & & 1.40 & 43.11 & 0.13 & 107.17 \\
\hline $\mathrm{CD}(p=0.05)$ & & NS & NS & NS & NS \\
\hline \multicolumn{6}{|l|}{ Zinc levels and methods of application } \\
\hline Control & 0 & 0.0 & 0.0 & 0.0 & 0.0 \\
\hline Seed coating of $0.6 \% \mathrm{ZnSO}_{4} \cdot 7 \mathrm{H}_{2} \mathrm{O}$ & 0.08 & 1269.8 & 25529.1 & 18.2 & 6991.8 \\
\hline Seed coating of $1.2 \% \mathrm{ZnSO}_{4} \cdot 7 \mathrm{H}_{2} \mathrm{O}$ & 0.15 & 1349.2 & 13478.8 & 17.3 & 7821.2 \\
\hline Seed coating of $1.8 \% \mathrm{ZnSO}_{4} \cdot 7 \mathrm{H}_{2} \mathrm{O}$ & 0.23 & 1327.2 & 9413.6 & 18.4 & 7210.1 \\
\hline 2-foliar spray @ 0.5\% ZnSO $.7 \mathrm{H}_{2} \mathrm{O}$ & 1.05 & 18.6 & 891.9 & 1.3 & 1487.5 \\
\hline 3-foliar spray @ 0.5\% ZnSO $.7 \mathrm{H}_{2} \mathrm{O}$ & 1.57 & 33.0 & 609.7 & 1.1 & 2961.2 \\
\hline $\begin{array}{l}1.2 \% \mathrm{ZnSO}_{4} .7 \mathrm{H}_{2} \mathrm{O} \text { seed coating+two foliar } \\
\text { spray @ 0.5\% } \mathrm{ZnSO}_{4} \cdot 7 \mathrm{H}_{2} \mathrm{O}\end{array}$ & 1.2 & 119.9 & 934.6 & 2.5 & 4722.9 \\
\hline SEm \pm & & 2.14 & 72.68 & 0.21 & 180.81 \\
\hline $\mathrm{CD}(p=0.05)$ & & 6.24 & 212.10 & 0.62 & 527.69 \\
\hline \multicolumn{6}{|l|}{ Interaction } \\
\hline \multicolumn{6}{|c|}{ Cultivation method within $\mathrm{Zn}$ levels and methods of application } \\
\hline SEm \pm & & 3.70 & 122.06 & 0.36 & 303.62 \\
\hline $\mathrm{CD}(p=0.05)$ & & NS & NS & NS & NS \\
\hline \multicolumn{6}{|c|}{ Zn levels and methods of application within cultivation methods } \\
\hline SEm \pm & & 3.02 & 102.78 & 0.30 & 255.70 \\
\hline $\mathrm{CD}(p=0.05)$ & & NS & NS & NS & NS \\
\hline
\end{tabular}

Note: Seed rate $30 \mathrm{~kg} \mathrm{ha}^{-1}$; Foliar spray of $0.5 \% \mathrm{ZnSO}_{4} \cdot 7 \mathrm{H}_{2} \mathrm{O} @ 500$ litres solution ha- ${ }^{-1}$

The perusal of the data revealed that the crop establishment methods did not have significant influence on PE of Zn in lentil. A widely varied range (1487.5-7821.2 kg grain increases per $\mathrm{kg} \mathrm{Zn}$ uptake) was seen among the treatments with regard to $P E$ of $Z n$ by lentil. However, with respect to $Z n$ levels and methods of application the treatments showed significant influence on PE of $\mathrm{Zn}$ in lentil. The highest PE was observed with application of seed coating @ $1.2 \% \mathrm{ZnSO}_{4} .7 \mathrm{H}_{2} \mathrm{O}$. In this case also, seed coated treatments showed higher PE than foliar applied treatments and as well as combined treatment (seed coating @ 1.2\% $\mathrm{ZnSO}_{4} .7 \mathrm{H}_{2} \mathrm{O}+$ two foliar sprays @ 0.5\% $\mathrm{ZnSO}_{4} \cdot 7 \mathrm{H}_{2} \mathrm{O}$ ).

Overall seed coating treatments showed significantly higher $\mathrm{Zn}$ use efficiency indices with respect to $A E, P F P, R E$ and $P E$. The ranges of $A E, P F P, R E$ and PE were widely varied. In this context Farooq et al. (2018) reported that seed coating produced by far the highest agronomic efficiency and apparent recovery, mainly due to the low amount of $\mathrm{Zn}$ applied. The agronomic, physiological and agro-physiological apparent recovery and utilization efficiencies was highest at lower level of $\mathrm{Zn}$ application and decreased with increase in $\mathrm{Zn}$ doses (Muthukumararaja and Sriramachandrasekharan, 2012; Shivay et al., 2015). The main cause for low RE for $\mathrm{Zn}$ is due to its rapid adsorption over soil organic matter and clay minerals (Hazra and Mandal, 1995) and its subsequent slow desorption (Mandal et al., 2000).

\subsection{Correlation studies}

Correlation between $\mathrm{Zn}$ levels and grain and stover $\mathrm{Zn}$ concentration of lentil was positive with $\mathrm{R}^{2}$ value of 0.5476 (Figure 1) and 0.4485 (Figure 2), respectively. Stronger correlation was found between $\mathrm{Zn}$ levels and grain $\mathrm{Zn}$ concentration of lentil. Correlation between $\mathrm{Zn}$ levels and grain 
and stover $\mathrm{Zn}$ uptake of lentil was also positive with $\mathrm{R}^{2}$ value of 0.2197 (Figure 3) and 0.2135 (Figure 4), respectively. So, stronger correlation was found between $\mathrm{Zn}$ levels and grain $\mathrm{Zn}$ uptake of lentil. Correlation between grain yield and grain $\mathrm{Zn}$ uptake of lentil was also positive with $\mathrm{R}^{2}$ value of 0.6576 (Figure 5). Similarly, correlation between stover yield and stover $\mathrm{Zn}$ uptake of lentil was also positive with $\mathrm{R}^{2}$ value of 0.5202 (Figure 6). However, stronger correlation was found between grain yield and grain $\mathrm{Zn}$ uptake.

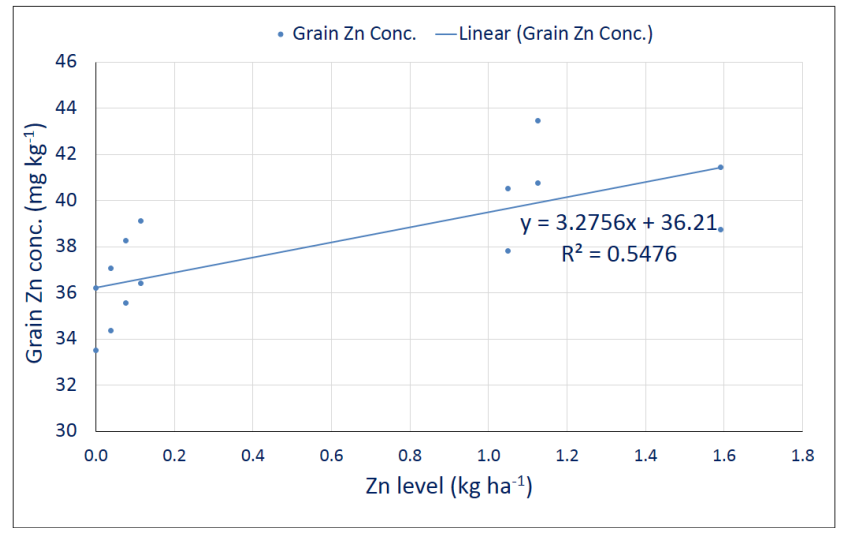

Figure 1: Correlation between $\mathrm{Zn}$ level and grain $\mathrm{Zn}$ concentration

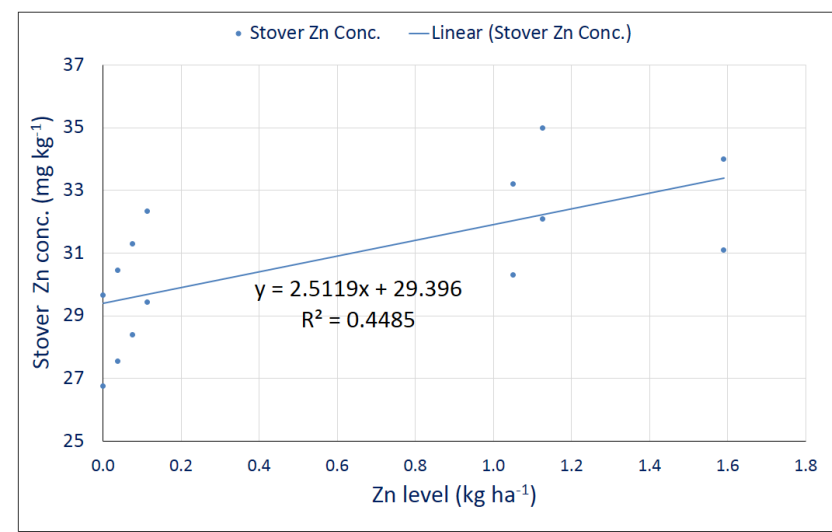

Figure 2: Correlation between $\mathrm{Zn}$ level and stover $\mathrm{Zn}$ concentration

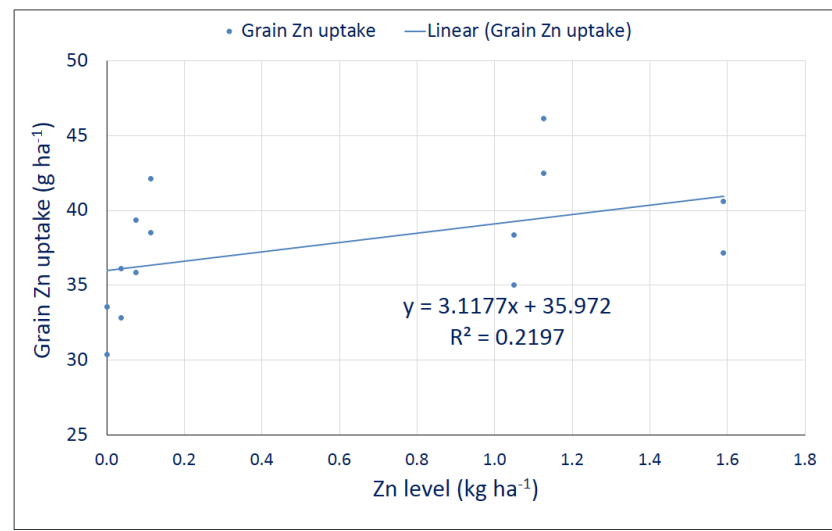

Figure 3: Correlation between $\mathrm{Zn}$ level and grain $\mathrm{Zn}$ uptake

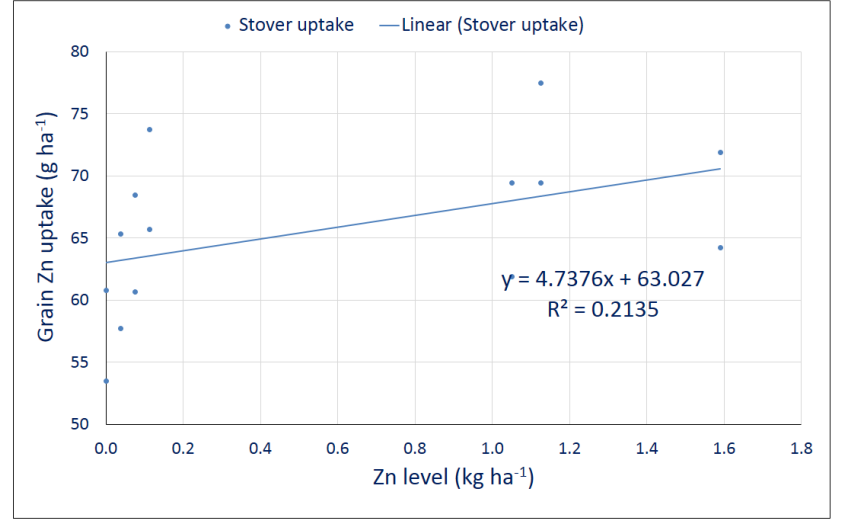

Figure 4: Correlation between Zn level and stover Zn uptake

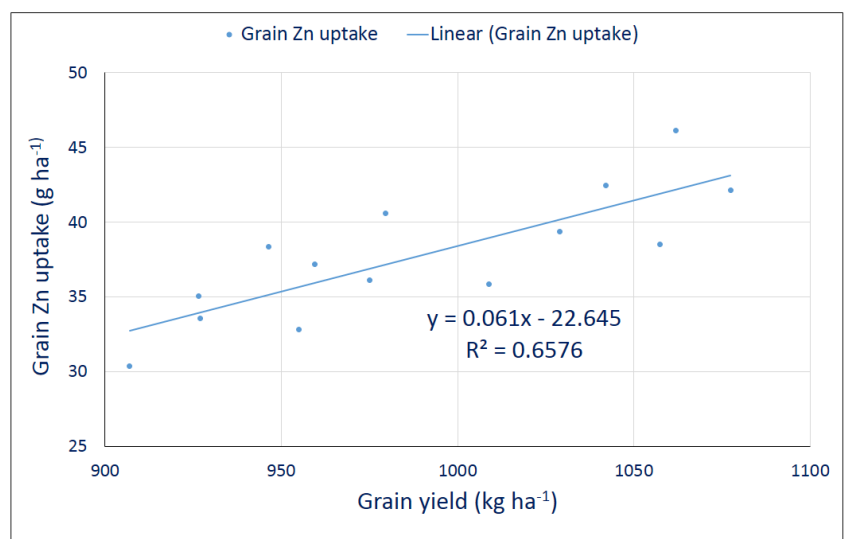

Figure 5: Correlation between grain yield and grain Zn uptake

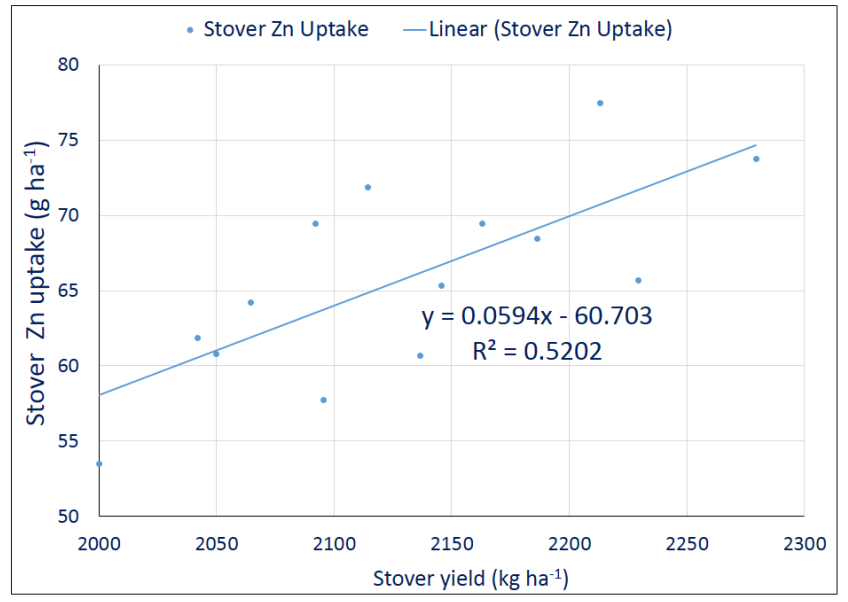

Figure 6: Correlation between stover yield and stover $\mathrm{Zn}$ uptake

\section{Conclusion}

The crop establishment methods did not show any significant influence on growth, yield and nutrient uptake by lentil. Application of seed coating @ $1.8 \% \mathrm{ZnSO}_{4} \cdot 7 \mathrm{H}_{2} \mathrm{O}$ showed significantly higher plant height, leaf area index, dry matter accumulation and yields. However, $\mathrm{Zn}$ concentration was recorded highest with application of $1.2 \% \mathrm{ZnSO}_{4} .7 \mathrm{H}_{2} \mathrm{O}$ seed coating+two foliar spray @ $0.5 \% \mathrm{ZnSO}_{4} \cdot 7 \mathrm{H}_{2} \mathrm{O}$. With regard to 
Zn use efficiency indices, seed coated treatments resulted into significantly higher efficiency than foliar application and combined application of seed coating and foliar spray.

\section{References}

Alloway, B.J., 2008. Zinc in soils and crop nutrition. Second edition, Published by International Zinc Association and International Fertilizer Industry Association, Brussels, Belgium and Paris, France. ISBN 978-90-8133-310-8, 134

Anonymous, 2021. Fertiliser statistics, 2019-20. The fertiliser association of India, FAl House, 10, Shaheed Jit Singh Marg, New Delhi.

Bentley, P.J., Grubb, B.R., 1991. Experimental dietary hyperzincemia tissue disposition of excess zinc in rabbits. Journal of Trace Elements in Medicine and Biology 8, 202-207.

Cakmak, I., 2000. Role of zinc in protecting plant cells from reactive oxygen species. New Phytologist 146, 185-205.

Dang, H.K., Li, R.Q., Sun, Y.H., Zhang, X.W., Li, Y.M., 2010. Absorption, accumulation and distribution of zinc in highly-yielding winter wheat. Agricultural Sciences in China 9(7), 965-973.

Disante, K.B., Fuentes, D., Cortina, J., 2010. Response to drought of Zn-stressed Quercus suber L. Seedlings. Environmental and Experimental Botany 70, 96-103.

Fageria, N.K., Baligar, V.C., 2001. Lowland rice response to nitrogen fertilization. Communications in Soil Science and Plant Analysis 32 (9-10) 1405-1429. DOI:10.1081/ CSS100104202.

Farooq, M., Ullah, A., Rehman, A., Nawaz, A., Nadeem, A., Wakeel, A., Nadeem, F., Siddique, K.H.M., 2018. Application of zinc improves the productivity and biofortification of fine grain aromatic rice grown in dry seeded and puddled transplanted production systems. Field Crops Research 216, 53-62.

Gomez, K.A., Gomez, A.A., 1984. Statistical procedures for agricultural research. Second Edition. John Wiley and Sons, New York, USA.

Hafeez, B., Khanif, Y. M., Saleem, M., 2013. Role of zinc in plant nutrition-a review. American Journal of Experimental Agriculture 3(2), 374-391.

Haider, M.U., M. Farooq, A. Nawaz and M. Hussain. 2018. Foliage applied zinc ensures better growth, yield and grain biofortification of mungbean. International Journal of Agriculture and Biology 20, 2817-2822. DOI: $10.17957 / \mathrm{IJAB} / 15.0840$.

Hazra, G.C., Mandal, B., 1995. Zinc adsorption in soils in relation to soil properties. Indian Journal of Agricultural Sciences 65(9), 659-664.

He, L.S., Yan, X.S., Wu, D.C., 1991. Age-dependent variation of zinc-65 metabolism in LACA mice. International Journal of Radiation Biology 60, 907-916.

Hemalatha, S., Platel, K., Srinivasan, K., 2007. Zinc and iron contents and their bioaccessibility in cereals and pulses consumed in India. Food Chemistry 102(4), 1328-1336.

Islam, M., Karim, M., Oliver, M., Hosain, M., Urmi, T.A., Hossain, M., Haque, M.M., 2018. Impacts of trace element addition on lentil (Lens culinaris L.) agronomy. Agronomy 8(7), 100.

Kabata-Pendias, A., Pendias, H., 2001. Trace elements in soils and plants, CRC Press, Boca Raton - London - New York - Washington D.C.

Kabir, A.H., Swaraz, A.M., Stangoulis, J., 2014. Zinc deficiency resistance and biofortification in plant. Journal of Plant Nutrition 177, 311-319.

Kasim, W.A., 2007. Physiological consequences of structural and ultra-structural changes induced by $\mathrm{Zn}$ stress in Phaseolus vulgaris I. Growth and Photosynthetic apparatus. International Journal of Botany 3(1), 15-22.

Kemp, C.D., 1960. Methods of estimating the leaf area of grasses from linear measurements. Annals of Botany 24(4), 491-499.

Khampuang, K., Lordkaew, S., Dell, B., Prom-u-thai, C., 2020. Foliar zinc application improved grain zinc accumulation and bioavailable zinc in unpolished and polished rice. Plant Production Science 24 (1), 94-102. DOI:10.1080/ 1343943X.2020.1797512

Khan, H.R., Mcdonald, G.K., Rengel, Z., 2000. Response of chickpea genotypes to zinc fertilization under filed conditions in South Australia and Pakistan. Journal of Plant Nutrition 23, 1517-1531

Lambers, H., Barrow, N.J., 2020. $\mathrm{P}_{2} \mathrm{O}_{5}, \mathrm{~K}_{2} \mathrm{O}, \mathrm{CaO}, \mathrm{MgO}$, and basic cations: pervasive use of references to molecules that do not exist in soil. Plant and Soil 452, 1-4. https:// doi.org/10.1007/s11104-020-04593-2

Lindsay, W. L., Norvell, W. A., 1978. Development of a DTPA soil test for zinc, iron, manganese, and copper. Soil science society of America journal 42(3), 421-428.

Llobet, J.M., Domingo, J.L., Colomina, M.T., Mayayo, E., Corbella, J., 1988. Subchronic oral toxicity of zinc in rats. Bulletin of Environmental Contamination and Toxicology 41, 36-43.

Mandal, B., Hazra, G. C., Mandal, L. N., 2000. Soil management influences on zinc desorption for rice and maize nutrition. Soil Science Society of America Journal 64, 1699-1705.

Maqsood, M.A., Schoenau, J., Vandenberg, A., 2016. Zinc fertilization of lentil for grain yield and grain zinc concentration in ten Saskatchewan soils. Journal of Plant Nutrition 39(6), 866-874.

Marschner, H., 1995. Mineral nutrition of higher plants, $2^{\text {nd }}$ Edn. London, UK Academic Press.

Mondal, M., Rahman, M. A., Akter, M. B., Fakir, M. S. A., 2011. Effect of foliar application of nitrogen and micronutrients on growth and yield in mungbean. Legume Research 34(3), 166-171.

Montenegro, J.B.V., Fidalgo, J.A.B., Gabella, V.M., 2010. Response of chickpea (Cicer arietinum L.) yield to zinc, boron and molybdenum application under pot conditions. Spanish Journal of Agricultural Research 8(3), 797-807.

Muthukumararaja, T.M., Sriramachandrashekharan, M.V., 2012. Effect of zinc on yield, zinc nutrition and zinc use efficiency of lowland rice. Journal of Agricultural 
Technology 8(2), 551-561.

Oktem, A.G., 2019. Effect of different zinc levels on grain yield and some phenological characteristics of red lentil (Lens culinaris Medic.) under arid conditions. Turkish Journal Agriculture and Forestry 43, 360-367.

Ozturk, L., Yazici, M.A., Yucel, C., Torun, A., Cekic, C., Bagci, A., Ozkan, H., Braun, H.J., Sayers, Z., Cakmak, I., 2006. Concentration and localization of zinc during seed development and germination in wheat. Physiologia Plantarum 128, 144-152

Palmer, C.M., Guerinot, M.L., 2009. Facing the challenges of $\mathrm{Cu}, \mathrm{Fe}$ and $\mathrm{Zn}$ homeostasis in plants. Nature Chemical Biology 5(5), 333

Pandey, A.C., Sanjay, S., Yadav, S., 2010. Application of ZnO nanoparticles in influencing the growth rate of Cicer arietinum. Journal of Experimental Nanoscience 5, 488-497

Panse, V.G., Sukhatme, P.V., 1985. Statistical method of Agricultural workers. ICAR, New Delhi, 152-159

Peck, A.W., McDonald, G.K., 2010. Adequate zinc nutrition alleviates the adverse effects of heat stress in bread wheat. Plant and soil 337(1), 355-374.

Phuphong, P., Cakmak, I., Yazici, A., Rerkasem, B., Prom-uThai, C., 2020. Shoot and root growth of rice seedlings as affected by soil and foliar zinc applications. Journal of Plant Nutrition 43(9), 1259-1267.

Prasad, R., 2003. Protein-energy malnutrition in India. Fertiliser News 48(4), 13-26.

Prasad, R., 2012. Micro mineral nutrient deficiencies in humans, animals and plants and their amelioration. Proceedings of the National Academy of Sciences, India Section B: Biological Sciences 82 (2), 225-33. DOI: 10.1007/s40011-012-0029-x.

Prasad, R., Shivay, Y.S., 2019. Fertilizer nitrogen and global warming - A review. Indian Journal of Agricultural Sciences 89(9), 1401-1406.

Prasad, R., Shivay, Y.S., Kumar, D., 2014. Agronomic biofortification of cereal grains with iron and zinc. Advances in Agronomy, 125, 55-91.

Prasad, T.N.V.K.V., Sudhakar, P., Sreenivasulu, Y., Latha, P., Munaswamy, V., Reddy, K.R., Sreeprasad, T.S., Sajanlal, P.R., Pradeep, T., 2012. Effect of nanoscale zinc oxide particles on the germination, growth and yield of peanut. Journal of Plant Nutrition 35, 905-927

Preetha, P.S., Stalin, P., 2014. Response of maize to soil applied zinc fertilizer under varying available zinc status of soil. Indian Journal of Science and Technology 7(7), 939.

Prom-u-thai, C., Rerkasem, B., Yazici, A., Cakmak, I., 2012. Zinc priming promotes seed germination and seedling vigor of rice. Journal of Plant Nutrition and Soil Science 175(3), 482-488.

Puste, A.M., Jana, P.K., 1988. Effect of phosphorus and zinc on growth patterns of pigeonpea (Cajanus cajan (L.) Millsp.) grown during winter season. Indian Journal of Plant Physiology 31(3), 243-247.

Shivay, Y.S., Prasad, R., Pal, M., 2014b. Effect of zinc fertilisation on grain and protein yield, nitrogen uptake and fertilizer use efficiency in chickpea. Indian Journal of Fertilisers 10(3), 24-27.

Shivay, Y.S., Prasad, R., Pal, M., 2014a. Genetic variability for zinc use efficiency in chickpea as influenced by zinc fertilization. International Journal of Bio-resource and Stress Management 5(1), 031-036. DOI: 10.5958/j.09764038.5.1.005.

Shivay, Y.S., Prasad, R., Pal, M., 2015. Effect of source and method of zinc application on yield, zinc biofortification of grain and Zn uptake and use efficiency in chickpea (Cicer arietinum L.). Communications in Soil Science and Plant Analysis 46(17), 2191-2200. DOI: 10.1080/00103624.2015.1069320.

Shivay, Y.S., Prasad, R., Rahal, A., 2010. Genotypic variation for productivity, zinc utilization efficiencies and kernel quality in aromatic rices under low available zinc conditions. Journal of Plant Nutrition 33(12), 1835-1848. DOI: 10.1080/01904167.2010.503832.

Singh, A., Singh, B.B., Patel, C.S., 1992. Response of vegetable pea (Pisum sativum) to zinc, boron and molybdenum in an acid Alsifol of Meghalaya. Indian Journal of Agronomy 37, 615-616.

Tavallali, V., Rahemi, M., Eshghi, S., Kholdebarin, B., Ramezanian, A., 2010. Zinc alleviates salt stress and increases antioxidant enzyme activity in the leaves of pistachio (Pistacia vera L.'Badami') seedlings. Turkish Journal of Agriculture and Forestry 34(4), 349-359.

Taylor, A.G., Herman, G.E., 1990. Concepts and technologies of selected seed treatments. Annual Review of Phytopathology 28, 321-339

Thamke, S.S., 2017. Studies on effect of graded levels of potassium and zinc on growth, yield, nutrient uptake and quality of pigeonpea. M.Sc. (Ag.) Thesis, Department of Soil Science and Agricultural Chemistry, Vasantrao Naik Marathwada Krishi Vidyapeeth, Parbhani (M.S.) 431402, India.

Tisdale, S.L., Nelson, W.L., Beaten, J.D., 1984. Zinc In soil fertility and fertilizers. Fourth edition, Macmillan Publishing Company, New York, 382-391.

Usman, M., Tahir, M., Majeed, M.A., 2014. Effect of zinc sulphate as soil application and seed treatment on green gram (Vigna radiata L.). Pakistan Journal of Life and Social Sciences 12(2), 87-91.

Vallee, B.L., Falchuk, K.H., 1993. The biochemical basis of zinc physiology. Physiological Reviews 73, 79-118.

Wastney, M.E., Aamodt, R.L., Rumble, W.F., Henkin, R.I., 1986. Kinetic analysis of zinc metabolism and its regulation in normal humans. American Journal of Physiology 251, R398-R408.

Watson, D.J., 1952. The physiological basis of variation in yield. Advances in agronomy 4, 101-145. Academic Press.

Zhang, Y.Q., Sun, Y.X., Ye, Y.L., Karim, M.R., Xue, Y.F., Yan, P., Meng, Q.F., Cui, Z.L., Cakmak, I., Zhang, F.S., 2012. Zinc biofortification of wheat through fertilizer applications in different locations of China. Field Crops Research 125, 1-7. 